

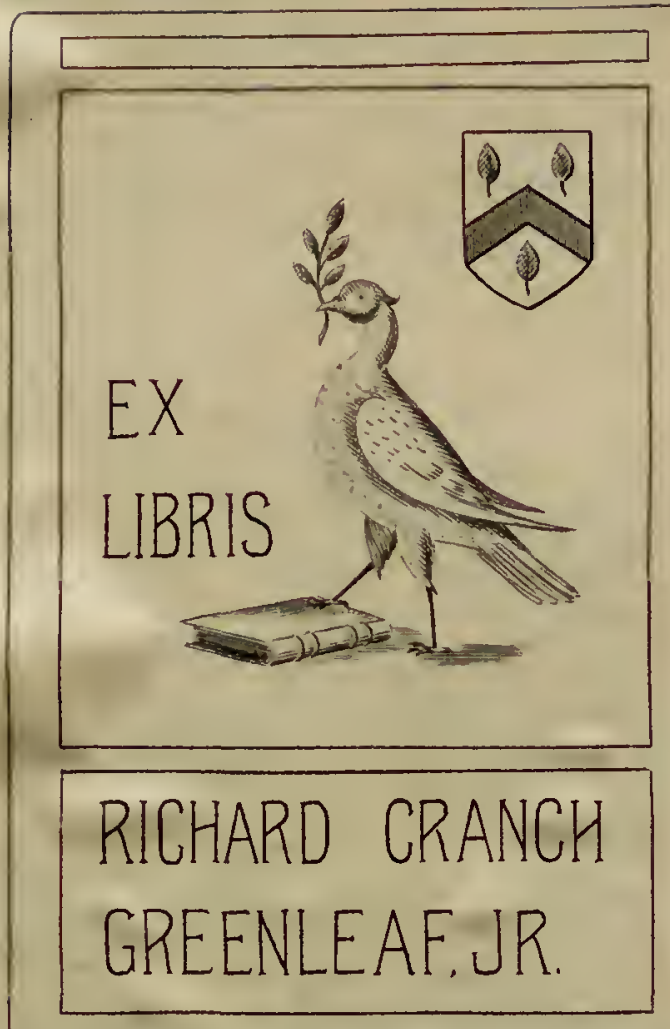

Ex Libris

$44 x$

6.2

CMM

Bequest of Richard Cranch Greenleaf in memory of his mother Adeline Emma Greenleaf 


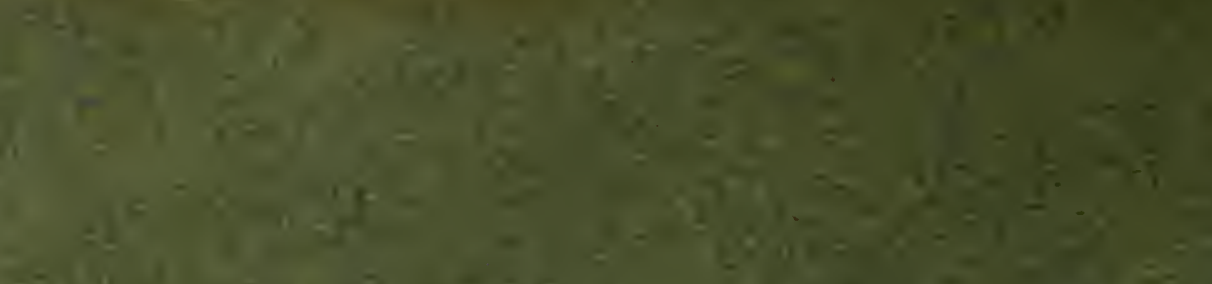

(1)

2.3.

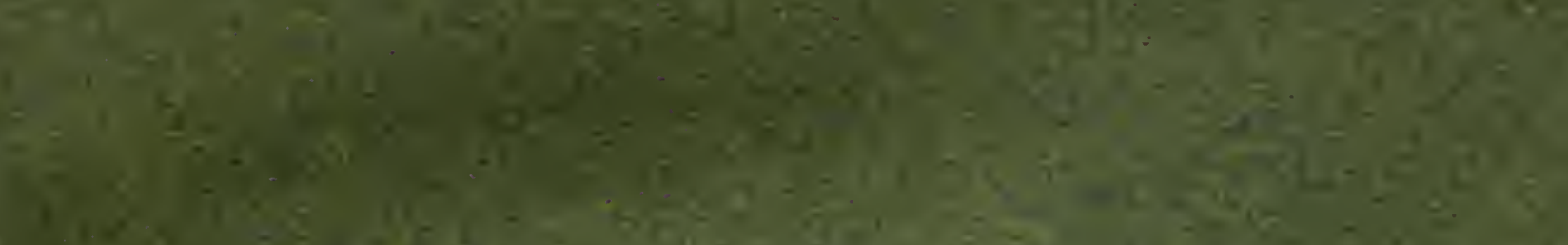
9.

*nis $x^{2}-2+20 \%$

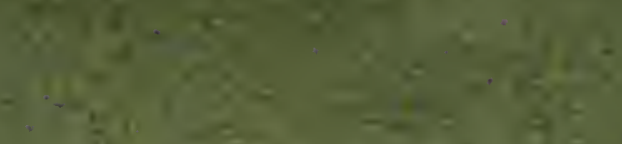

2

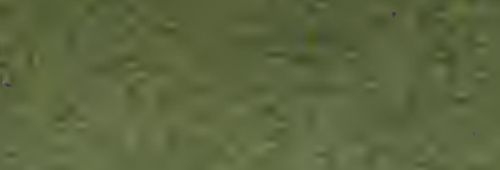

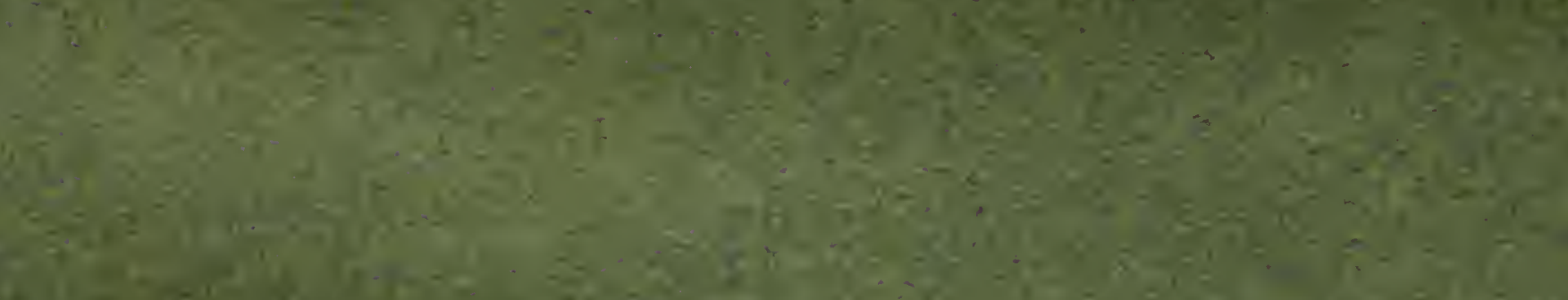

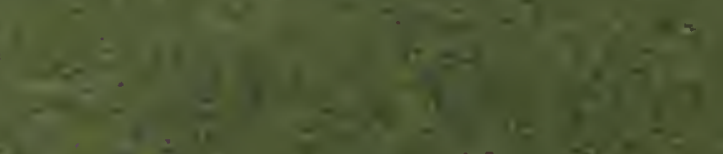
12 $=-1$ $2 \cdot x^{2}$ 8 $x^{2}-\infty$

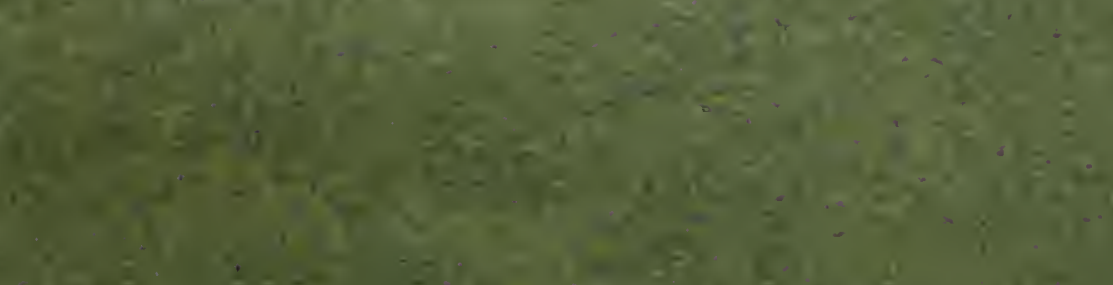

$+2$

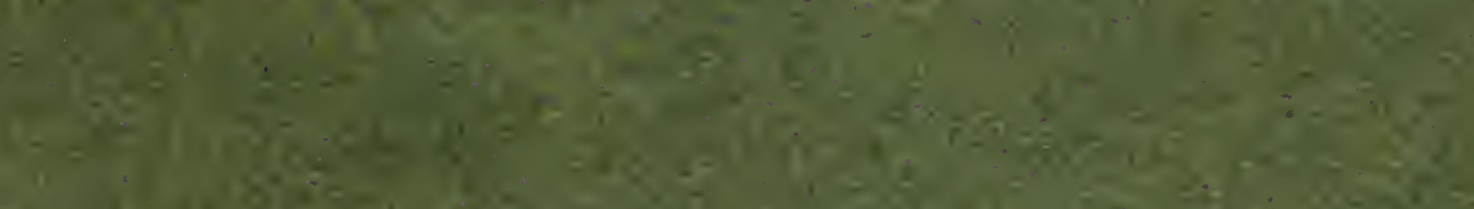

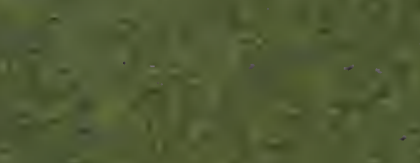

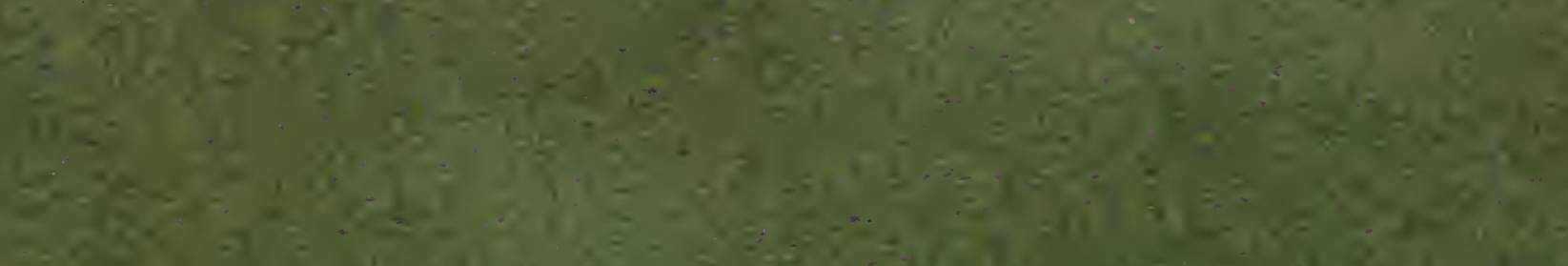

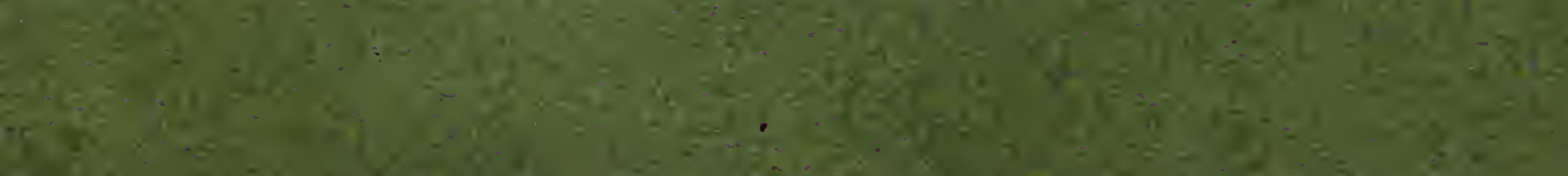
(9) $11^{1}=$ $\frac{5}{2}$

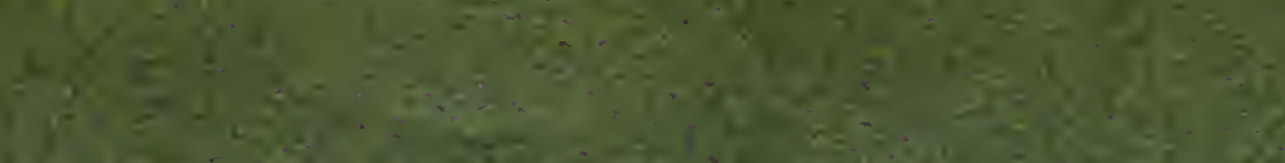

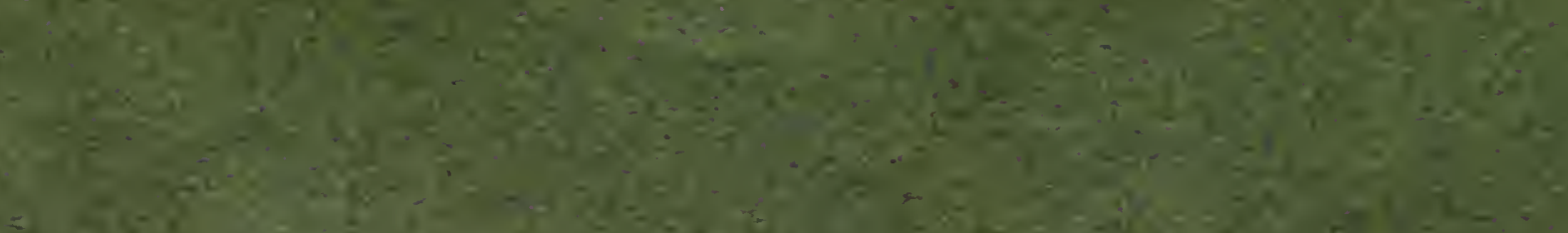

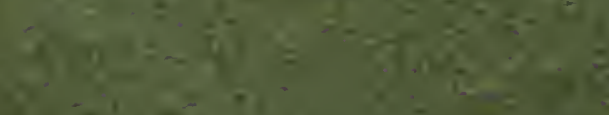
$\frac{-1}{x+3}=\frac{9}{2+1}$ $-1,2$ 10 1 



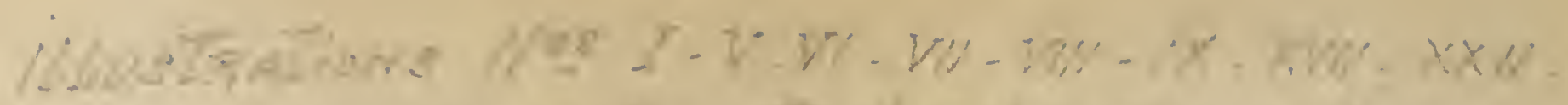

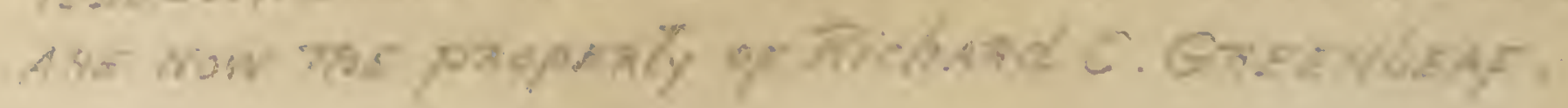




LES POINTS DE FRANCE 


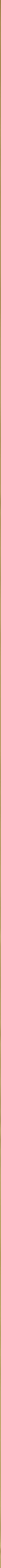




Les Points de France 



\section{INTERNATIONAL EXHIBITION \\ $1900 \cdot P A R I S$ \\ RETROSPECTIVE COLLECTION \\ CLASS $84 \cdot$ LACE \\ REPORT OF}

MONSIEUR ERNEST LEFEBURE

SECRETAIRE DU CONSEIL DU MUSEE DES ARTS DECORATIFS

FABRIQUANT DE DENTELLES

8 RUE DE CASTIGLIONE, PARIS

TRANSLATED BY

MARGARET TAYLOR JOHNSTON

NEW YORK, MCMXII 



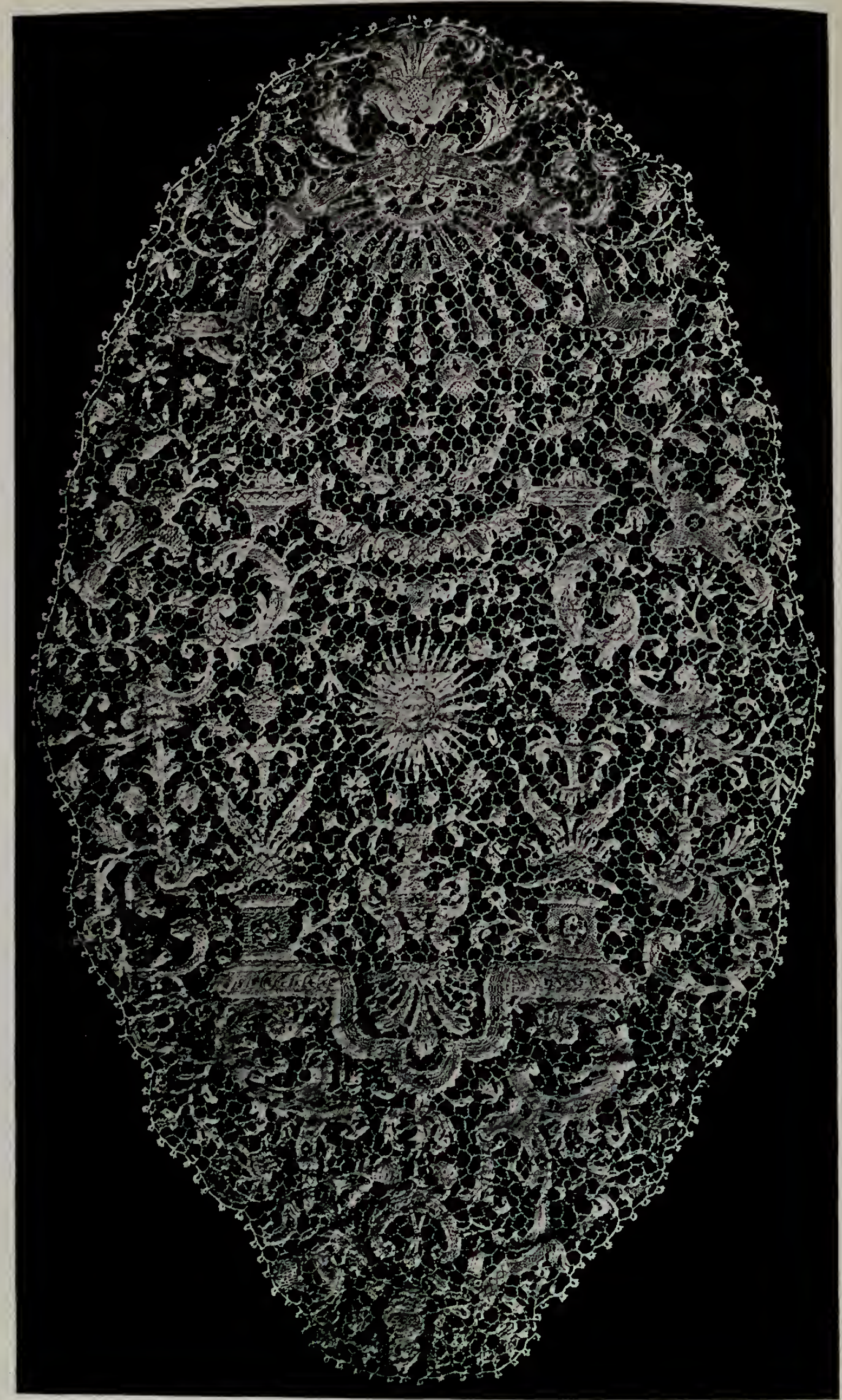

I. MEDALLION, LE ROI SOLEIL (LOUIS XIV)

STYLE OF BÉRAN, FIRST PERIOD OF THE POINTS DE FRANCE COLLECTION OF MADAME PORGÈS 


\title{
Les Points de France
}

\author{
B Y \\ ERNEST LEFEBURE
}

TRANSLATED BY

MARGARET TAYLOR JOHNSTON

NEW YORK : MCMXII 


\section{CONTENTS}

List of Illustrations

PA GE

Preface By Margaret Taylor Johnston

I 7

Les Points de France By Ernesl Lefébure

25 


\section{ILLUSTRATIONS}

I. Medallion, Le roi soleil (Louis XIV)

P A G E

Style of Bérain. First period of the Points de France

Collection of Madame Porgès

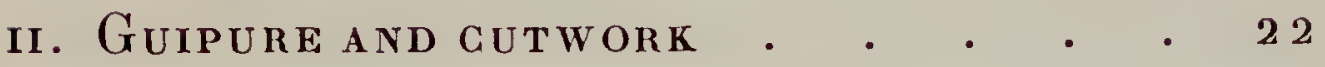

Sixteenth century

Collection of Monsieur l'abbé Bert

iti. Magasin de Dentelles. La galerie du

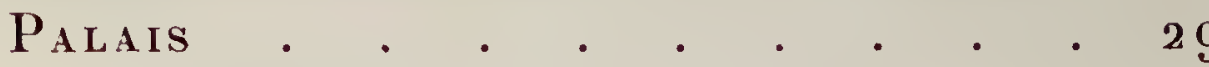

By Abraham Bosse

Bibliothèque nationale

iv. Portrait of Colbert $\quad . \quad$. $\quad . \quad$. 34 Bibliolhèque nationate

v. Guipure in high relief, Venetian style 38 Seventeenth century

Collection of Madame Porgès

Vi. Altar frontal of guipure in relief, Framing the figure of Sainte Thérèse 40 Seventeenth century Collection of Madame Porgès

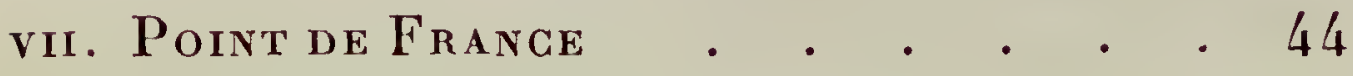
Seventeenth century Colleclion of Monsieur Iklé 


\section{$[14]$}

vili. Rabat of Point de France, with figURES, DOLPHINS, AND WARLIKE ATTRI-

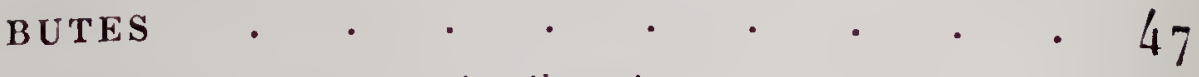

Second hatf of the seventeenth century

Collection of Madame Porgès

ix. Border of Point de Frange • • . 50

Seventeenth century

Cottection of Madame Porgès

x. Flounce of bobbin-lage. Eagles adorING THE SUN . . . . . . . . 54

End of seventeenth century

Metropolitan Museum of Art

xi. Deep border for an alb of Point de France • . . . . . . . . 55

Period of Louis XIV

Collection of Monsieur l'abbé Bert

XiI. Deep flounce of Point de France 58

End of seventeenth century

Collection of Madame Lionet Normant

xili. Deep flounce of Point de France . 59 Early eighteenth century

Cottection of Madame Doistau

Xiv. Rabat OF BOBBIN-LACE • • . . 62

End of seventeenth century

Collection of Madame Doistau

Xv. Deep flounge • • • • • • • . 63

Period of the Regency

First hatf of the eighteenth century

Metropotitan Museum of Art 


\section{$[$ I 5 ]}

xvi. Rabat of Point de France . . . 66

Period of the Regency

Collection of Madame Cornély. Now at the Musée des Arts décoratifs

xvit. Point de Frange • . . . . . 67

Period of the Regency

Collection of "Madame Porgès

xvili. Rabat of bobiin-lace. Degign of peaGOCKS AND PAGODAS . . . . . 70

Period of Louis $X V$

Collection of Madame Doistau

xix. Bertha, needle-point. Design of HUNTSMEN AND OTHER MOTIVES IN THE STYLE OF DRESDEN GHina • • • • 7 I

Period of Louis $\mathrm{XV}$

Collection of Hadame la comtessc Foy

xx. Flounge of Point d'Argentan • . 76

Style of Louis $X V$

Middle of the eighteenth century

Musée des Arts décoralifs

xxi. Flounge of Point d'Argentan • $\quad 77$

Style of Louis XVI

Latter half of the eighteenth century

Musée de la Chambre de Commerce de Lyon

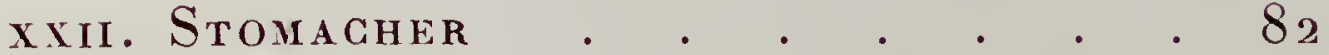

First Empire

Collection of Madame Porgès

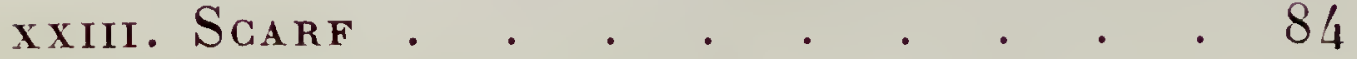

Period of the Directory

After a photograph in the Musée des Arts décoratifs 


$$
\text { [ I } 6 \text { ] }
$$

\section{xxiv. Bedspread from La Malmaison • • 87}

From a pholograph in the Library of the Musée des Arts décoratifs

xxy. From an Engraving in the Musée

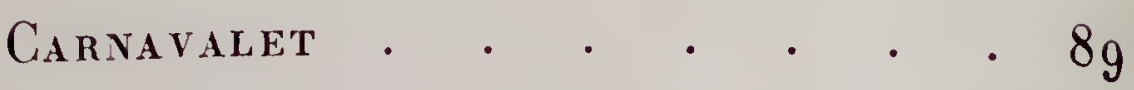

xxvi. Address of a Lace-merchant • 9 i Period of Louis XVI

Xxvil. Queen Marie-Amélie • • • • 95 Painting by Winterhalter Iusée de Versailles

xxvili. Book-cover in Point Colbert and Point D'Argentan * • • • • Nineteenth Century Library of the Valican

XXIX. Winders FOR LAGE • • • • • IOO Musée du Trocadéro 


\section{Preface}

\section{BY THE TRANSLATOR}

\section{A}

$\mathrm{N}$ important part of the artistic life of Paris consists of the loan collections which, from time to time, bring into view the private treasures of the nation, and interesting indeed is the company of connoisseurs who assemble for the Private View.

The exhibition of igoo thus brought together many of the more important French laces, and notably the Points de France of the period of Louis XIV, marvels of work and design, created at the command of the King and of his great minister Colbert, from Venetian tradition and inspiration.

An interesting brochure by Monsieur Ernest Lefébure was written at that time for private distribution, to explain the origin of these beautiful laces. It is much to be regretted that this booklet is now entirely out of print, for it gives a simple and consecutive account of the greal period of lacemaking in France, and of the evolution of a new and characteristic French style from the earlier Venice Points, on lines adapted to lace by leading artists of the day-Lebrun, Bérain, Bailly, Bonnemer. The large number of illustrations, correctly named as to both lind and period, makes this pamphlet a little gallery of art, which should 


\section{$\left[\begin{array}{lll}18 & ]\end{array}\right.$}

reach many who may never have the rare chance and pleasure of being in Paris during the few weeks when a loan collection is on exhibilion. An even more extensive collection of laces was shown in 1 9o6 al the Musée des Arts décoratifs, a museum that owns several very beauliful Points de France.

It therefore seems a valuable contribulion to the literature of lace, to translate some few of these interesting pages for an American public, which already has a number of specimens at hand in our own Metropolitan Museum of Arl in New York. A very few years ago, these Points de France were as entirely beyond our reach as the Memlings or Botticellis of European galleries; but generous gifts and bequests have slarled an historic sequence, which the future will cerlainly complete.

\section{Margaret Taylor Johnston}

New York-Paris, 1912. 
Chapter I 




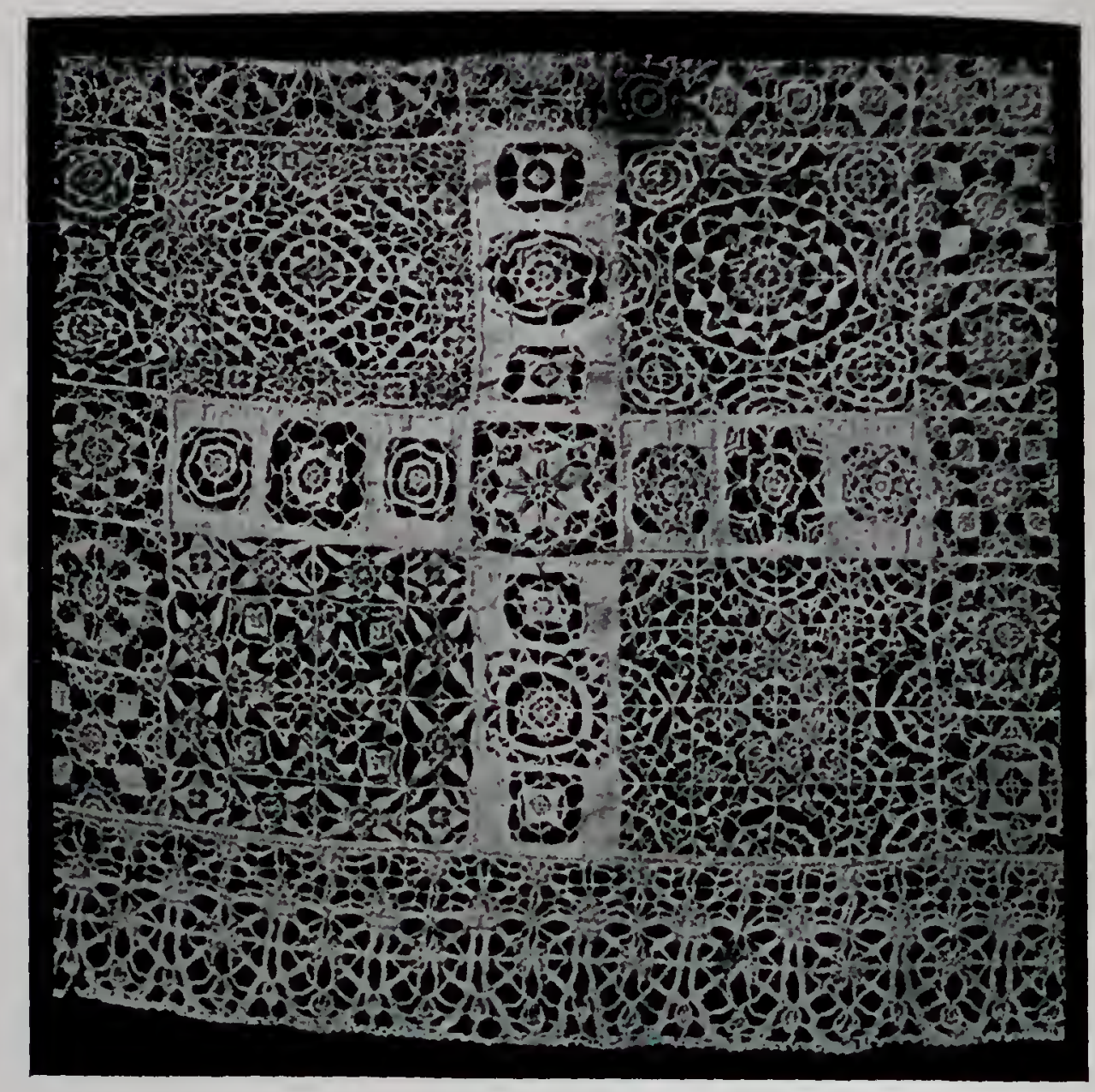

II. GUIPURE AND CUTWORK SIXTEENTH CENTURY

COLLECTION OF MONSIEUR L'ABBÉ BERT 


\title{
Les Points de France
}

\author{
HAND-MADE LACE
}

\section{Chapter I}

Lace before the time of Colbert

\begin{abstract}
$\mathrm{T}$
HE Retrospective Exhibition held in Paris in I 9oo, included in its broad program all branches of human activity. Such a colossal task could with difficulty be wholly successful in the precipitate haste which reigns during the installation of an International Exhibition. Much effort is required to attract to these great international fairs the commercial manufactures of the day, but still greater effort is required to obtain specimens of ancient date, jealously guarded by collectors, who often will not part with them at any price, nor will they lend them without much
\end{abstract}




\section{[24]}

solicitation, always fearing loss and injury. On this occasion, many contributors were notified too late, or had not understood that the Retrospective Centennial Exhibition was not limited to the products of the nineteenth century. Under these conditions, a number of collectors did not assist in perfecting the Exhibition, as they might have done under more favorable circumstances. Many sections - and notably that of Lace - showed blank spaces which prevented the public from obtaining a complete understanding of these industries from their origin to the present day. This is the more to be regretted, as specimens of the comparatively recent art of lace might have been brought together far more easily than examples of other arts the past of which must be sought in the dusk of ages.

We seek therefore to fill some of these blank pages.

Lace does not seem to have altained to the importance of an industry before the fifteenth century. Those who have written upon this subject since Mrs. Bury-Palliser, the first author who went into it seriously, have found no trace of lace in pictures or in sculpture antedating this period. Scant use would there have been for lace in those days, when linen was both rare and coarse. It is said that Charles the Simple, who died in 929 A.D., possessed but three shirts! And when Isabeau de Bavière in I 385 A. D., 


\section{$[25]$}

coming to marry King Charles VI, brought three dozen chemises in her trousseau, at the court of France this was thought an extraordinary degree of luxury.

It is through fine embroidered linen that lace stitches first came into use. The returning Crusaders brought with them many things which initiated the French nobility into the luxury of the Orient. And when Francis I returned from his expedition to Italy, where, said he, "All is lost save Honor" (tout fors l'honneur), he had acquired a taste for the beautiful linen-works and rich trimmings, the fashion of which was beginning to spread in the opulent provinces of Genoa, Florence, and Venice, where princes and artists were ardently encouraging the Renaissance of all the arts.

The fine linen embroideries in openwork, drawnwork, and cutwork, finished with round or pointed edges, first showed the need of lace. Such words as lace, needle, point, bobbins, have undoubtedly an Italian sound. ${ }^{1}$

1 This is said of the French rather than of the English words.

Lace-(Ilal: trina, merli-Fr: dentelle) Point-(Punto-le point)

Needle - (Ago or aco-aiguille) Bobbins - (fusselli-fuseaux)

Modern criticism attributes increasingly to Italy the origin of the beautiful linen-works which led up to needle-point lace. These were being slowly evolved for a century or more, before the great cinque cento (sixteenth century), when the perfecting of the manufacture of needles and the printing of the Pattern Books caused these embroideries to spread rapidly throughout Europe, where they became the work of all classes of society. 
From its first appearance lace was used as extensive-ly at the Court of France, as at the Courts of Germany, England, and Spain, then dominant in Flanders. It also seems to have been worked everywhere with the needle, or bobbins, at about the same period, but through local influences brought to bear upon the workers, important centers of production were established, which surpassed all other places. Many designs were obtained from Italian artists who, in competition with each other, produced the Pattern Books (recueils de dessins) now so rare, the best known of which is called Les singuliers et nouveaux pourctraits et ouvrages de lingerie . . . dédiés à la Royne, par le signor Vinciolo. ${ }^{1}$

In France, where all industry was controlled by corporations, or guilds, it was the makers of passements

1 An incomplete list of those books is to be found in Mrs. Bury-Palliser's History of Lace, and in Broideries et dentelles by M. E. Lefébure.

Frédéric Vinciolo, "Vénitien," as he styles himself, left Venice for Paris, and drew designs for the queens and great dames of France, in the late sixteenth and early seventeenth centuries. His book (divided into two partsfilet brodé, and point coupé, or poinct de couppé in the sixteenth century spelling) passed through many editions, and through his many plagiarists in Germany and England he influenced the entire production of the North, while Franco, Vecellio, Parasole, Passerotti, and many other artists and designers drew for the workers of the South.

Vinciolo classes many kinds of work under the single name of cutwork (point coupé), making no attempt to translate the Italian term reticello narrow lines of geometric open work, and the rosaces of increasing size and importance - which attained to their most extravagant development in the ruffs of Marie de Medici and Queen Elizabeth. Note by the Translator. 


\section{[ 27$]$}

(passementiers) who had the monopoly of the new production, and the first laces were therefore called passements.

We will not treat in detail the history of lace under the Valois. Its deep pointed edges were seen bordering the ruffs (fraises) which framed the heads of the noble dames and courtiers. In the early days of the art, few and rare were the pictures and portraits which showed on the raiment a decoration at all resembling lace; but from the time of Francis I, it was everywhere, and we find numerous and interesting examples of the succeeding styles. During the reigns of Henry II (i 547), Francis II ( 1559), Charles IX ( 1560), and Henry III ( 1574$)$, the Queens Catherine de Medici and Mary Stuart left abundant evidence of their love for lace. They introduced the squares of embroidered net and guipure, with cutwork squares worked into the linen, which since that time have been so much used for household furnishings. Henry IV, a jovial prince, would also have patronized the lace-making art, but he was restrained by his Minister Sully, who with $\mathrm{Hu}$ guenot austerity said to him, "What you need are iron and soldiers, rather than silks and laces for decorating your gallants." Under Louis XIII, luxury knew no bounds, in spite of the numerous edicts for the restriction of extravagance. We are reminded that Cinq Mars had three hundred sets of collars and cuffs of lace, when he was arrested by Richelieu. 


$$
\left[\begin{array}{ll}
28 &
\end{array}\right]
$$

The fashion for the plaited collars worn under the Valois, changed to that of large flat collars, showing well the design of the lace, which was also used for the cuffs, and even for the boots. Very accurate information as to the laces worn at this period is to be found in the interesting engravings of Abraham Bosse; they show the costumes, and even the shops with their wares displayed.

It is under Louis XIV, and his great minister Colbert, however, that we find the highest achievement in lace-making in France. It is here that we willingly pause in our story, for examples of the most beautiful needle-points of this period were shown at the Retrospective Exhibition of $1900 .{ }^{1}$

1 A copy of the French pamphlet has been given by the author to the Library of the Metropolitan Museum of Art.

Part II, Machine-lace, is omilled in this translation. A few of the illustrations of Part I in the original booklet not being available, these have been replaced by the enlarged size of others, and by three laces from the collection of the Metropolitan Museum. Note by the Translator. 


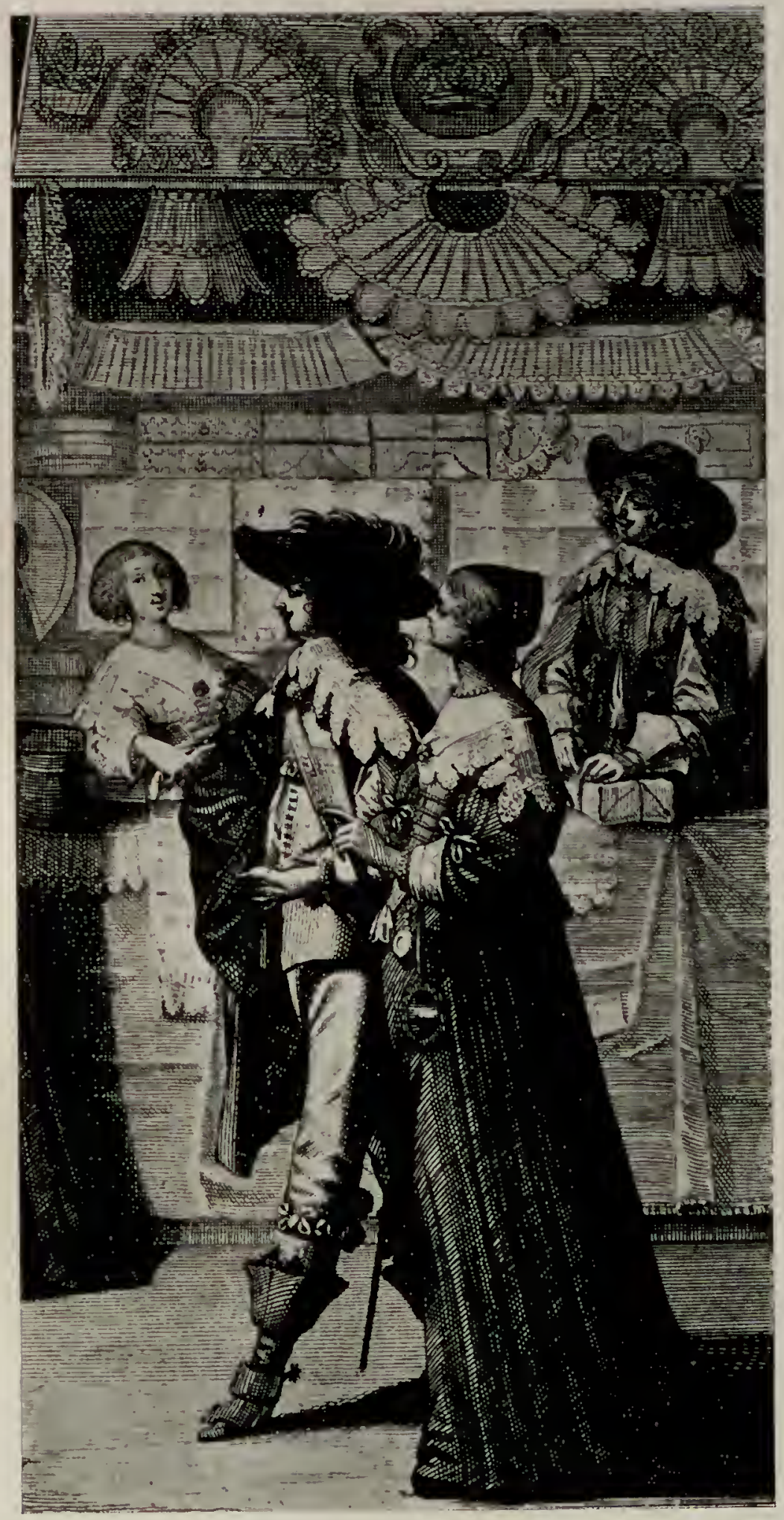

III. MAGASIN DE DENTELIES. LA GALERIE DU PALAIS BY ABRAIIAM BOSSE

BIBLIOTIËQUE NATIONALE 

Chapter II 




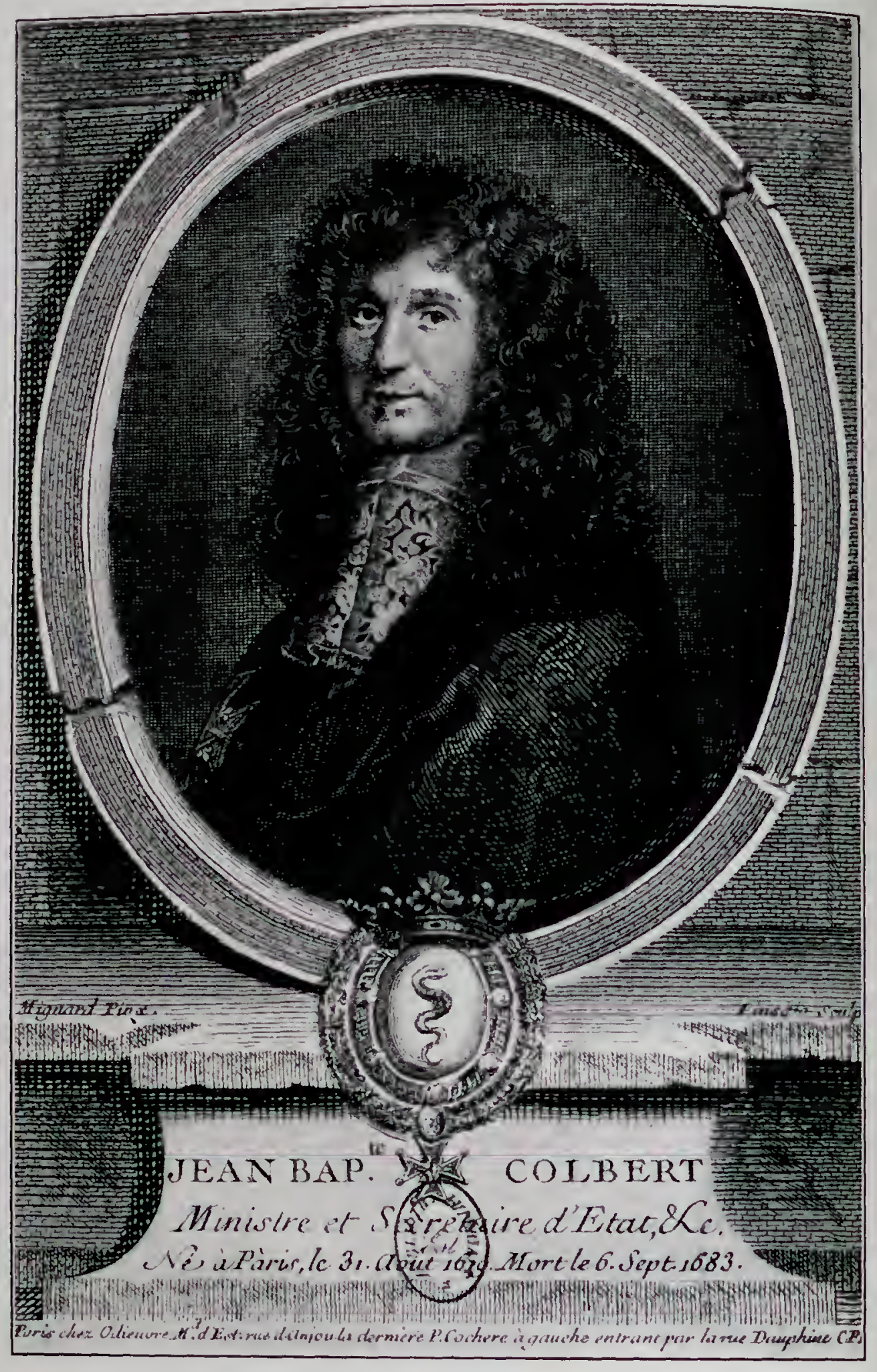

IV. PORTRAIT OF COLBERT

BIBLIOTHEQUE NATIONALE 


\section{Chapter II}

Lace from the time of Colbert to the Revolution

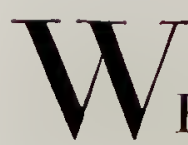

HEN Colbert founded the Royal Manufactories, his intention was that they should excel in those branches where French supremacy was the least assured. Porcelains, mirrors, and furniture received his most earnest attention, and even greater thought was expended upon lace and tapestry.

Investigation into the subject of the lace-making art showed that the industry already existed in several provinces of France, but that very inferior work was produced. Colbert found that in the great luxury at the Court of Versailles, the costly rabats of Venice Point, worn by the most fastidious of the courtiers, were brought at great expense from Italy. His efforts were therefore directed to perfecting the manufacture by furnishing the necessary means for learning to make as good needle-point lace as that of Venice. His correspondence with Monsignore de Bonzy, the royal ambassador to the Venetian Republic, gives every detail of this enterprise.

In Paris, the first manufactory was established in the Hôtel de Beaufort. But it was at Alençon and Ar- 


\section{$[36]$}

gentan that the industry was most firmly implanted, and threw out roots strong enough to survive until the present day, although after the death of Colbert, it lacked the powerful protection which had guarded its early years.

The first laces were made under the direction of lacemakers brought from Venice, and were worked in exactly the same way as those produced in the city of the Doges. Colbert was so well pleased that he wrote to his ambassador, "I can now say that collars worked in relief are produced in this reah, which are as beautiful as those of Venice." This explains the hesitation of connoisseurs in attributing to Venice, or to our French manufacture, the few rare and beautiful specimens of this period still extant, such as the splendid rabat at the Musée de Cluny.

We must here note that in the sixteenth, seventeenth, and eighteenth centuries, men wore as much lace as women, and were as much interested in the quality of the work as were the great dames themselves. It is to this two-fold interest, no longer existing, that lace owed its high standard of perfection, from the time of Colbert to the Revolution. The century between

\footnotetext{
${ }^{1}$ The Colbert correspondence with reference to the Points de France was first published in the third edition of Mrs. Bury-Palliser's Histony of LACE, 18 75 - followed by Seguin, E. Lefébure, and Madame de Laprade, LE Poinct DE Fraxce, all adding their quota of knowledge through the study of the documents, as well as the laces, of this great epoch in the art of lace in France. Note by the Translator.
} 



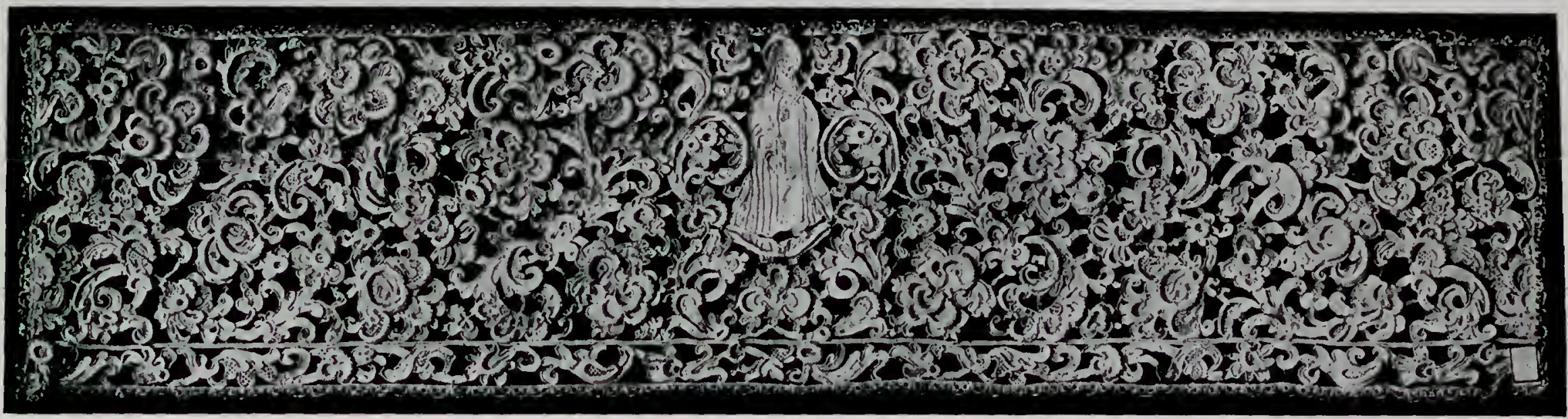

VI. ALTAR FRONTAL OF GUIPURE IN RELIEF, FRAMING THE FIGURE OF SAINTE THER ÈSE SEVENTEENTH CENTURY

COLLECTION OF MADAME PORGES 


\section{[4I]}

I 665 and ${ }_{17} 80$ can be called the Golden Age of lace, and nothing has surpassed the production of this wonderful period.

The Retrospective Exhibition showed an altar frontal, in the collection of Madame Porgès, which gives a clear idea of the laces resembling the rich Venice Points, but worked in France at the time of Colbert. The figure of Sainte Thérèse clasping a crucifix is in the center, framed by a design of flowered scrolls in relief.

The same collection has another piece of similar work, but earlier in date. The flowers are certainly drawn under Venetian influence, but they are surrounded by a rich foliage which recalls the beautiful velvet coverings for furniture made during the reign of le Grand Roi.

A few designs during the eighteenth century still followed the Italian tradition, and it is to this period that the square collar (col à plastron) of the Doistau Collection can be attributed, in which the branching scrolls are entwined with a crown. But the artists of the Louvre, charged with the task of designing for the Royal Manufactories, soon freed themselves from all foreign influence, and created those exquisite laces, so truly named by the King himself, "Les Points de France."

Another beautiful fragment of this period was shown in the Porgès Collection, only a part, perchance, of a 
more important whole, ${ }^{1}$ but as it now exists, forming a motive complete in itself. (Frontispiece.) In the center is enthroned The Royal Sun (Le roi soleil, Louis XIV), surmounted by a sort of daïs, and flanked on either side by trophies formed of crossed swords and standards. Never was better use made of the combined artistic resources of needle-point lace! From a grounding of grands réseaux picotés, ${ }^{2}$ an ideal architecture detaches itself, forming a charming frame

${ }^{1}$ A deep flounce of this design, five or six meters in length, from the collection of Madame Rigaud is, at the moment of writing, on exhibition at the Lyceum Club of Paris, in a small loan collection of laces, fans, and miniatures, brought together by the President of the Club, the Duchesse d'Uzès douairière.

The motive of the Royal Sun is seven times repeated, with the arms and the ideal architecture; accentuations of relief in the deep pointed border appear to weigh down the folds of lace. Nothing more charming could be imagined! The artists of the Louvre, to whom was confided the task of creating the new style of the Points de France, adapted the massive architectural lines of the period of Louis XIV, to the delicate technique in which they were to be reproduced, a lighter effect also found in many of the Venetian laces of the end of the century. But men of lesser ability in the early eighteenth century often lost this perfect sense of the proportion of design and grounding. Note by the Translator.

${ }^{2}$ The grande bride picotée grounding of the Points de France, is an hexagonal mesh buttonholed on each side, further enriched with one or two picots or knots. This is an extension of the earlier single bride that united the various parts of the design, when it was not self-supporting, and explains the use of the term dentelles a fond de brides, which we so often find applied to these laces of Venice and France, of the central or barocco period, succeeding that of geometric or conventional design, and preceding the use of many groundings in the eighteenth century laces. Note by the Translator. 



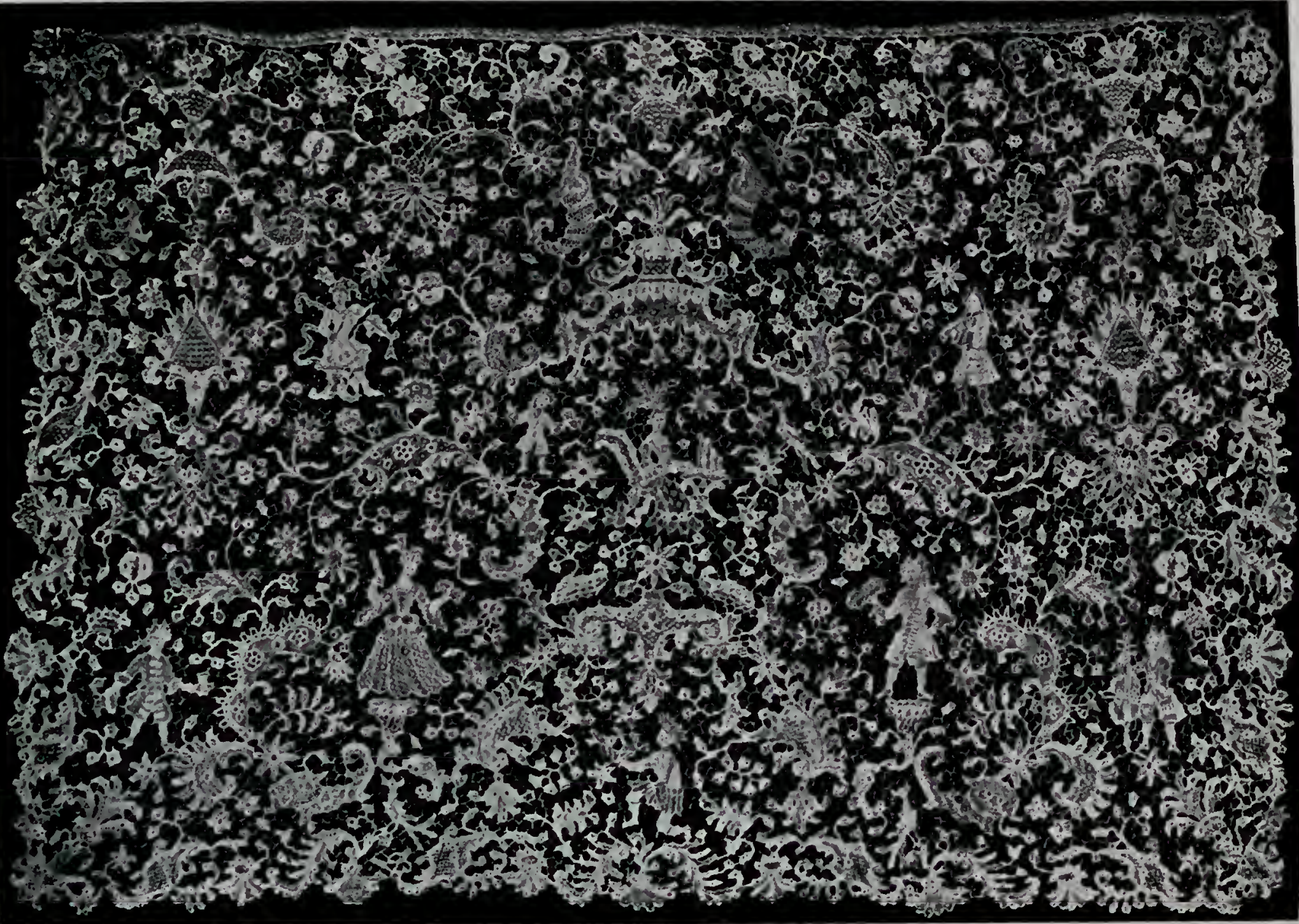




\section{$[45]$}

for the triumphant emblem of the Sun, which is made more effective by its surroundings. The lines are formal but light; a delicate embroidery in relief, used with consummate art, accentuates the imporlant parts, and gives to the whole a feeling of distinction which has never been surpassed.

The fact cannot be contested that these Points de France of the great epoch of the Royal Manufactories, are, from the point of view of artistic composition, infinitely superior to the whole production of Venice, which is restricted to an ever-recurring arrangement of scrolls more or less elaborately worked.

The marriage of the grandson of Louis XIV, the young Duke of Bourgogne, to the Princess MarieAdelaide of Savoy, was the union of two children, the duke being fourteen, and his betrothed but eleven years of age. The Points de France made for this occasion are represented by a charming little piece in the Iklé Collection. It is a square which may have been used for a jabot. The work is similar, and the design has the same characteristics as the preceding one, but already there is less distinction and precision in the style; the composition is more mannered, although it retains its former elegance. A princess, sitting under a daïs in the center, seems to be playing on a harpsichord or organ. A little prince behind her is singing, perchance, as beautifully as the bird on the other side; two figures higher up play on other instruments 


\section{$[46]$}

- the courtier on the violin, and the lady in front on a little lyre or harp; below another lady and gentleman sing, each holding a piece of music, and two musicians play the violoncello and the castanets, while a child kneeling offers flowers. All is gay and sparkling, and in proportions which suit admirably the piece of lace.

The specimen of similar shape in the Porgès Collection is even more remarkable. In the center stands a young man, dressed as a warrior of ancient days; the helmet, with a double-headed eagle, ${ }^{1}$ is surmounted by the closed crown of a royal prince, supported by two cherubs; higher still a little Bacchus is astride a cask. On the right and left are dolphins (dauphins), side by side, which emblem clearly indicates that the design is meant for the heir to the throne. Two children, like the one mentioned in the preceding piece, kneeling offer gifts. Genii float in the delicate foliage, bringing palms and crowns. These are destined for the two young warriors with helmets, standing lower than the more important figure, who walks triumphant over a mass of arms and standards! This is evidently the Dauphin, son of Louis XIV, here represented in triumph with his two sons, the Duke of

1 This figure with the double-headed eagle is seen in the Oeuvres complètes of Bćrain in the Library of the Musée des Arts décoratifs, Paris. Note by the Translator. 


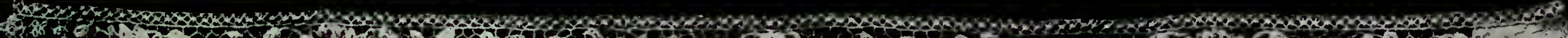

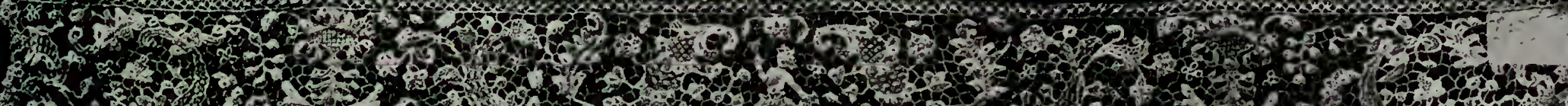

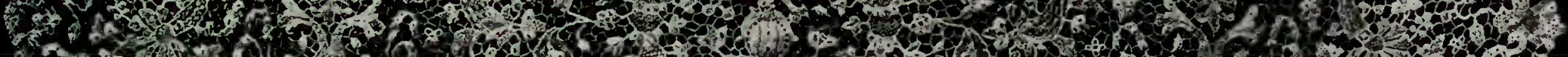

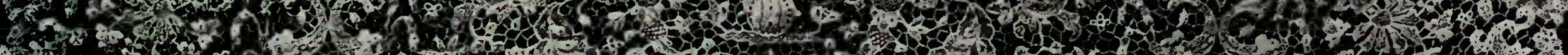

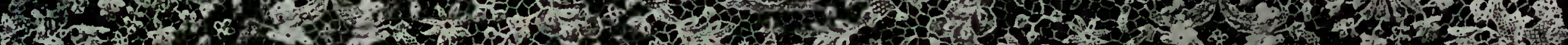

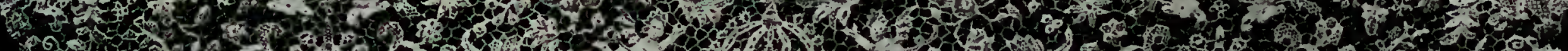

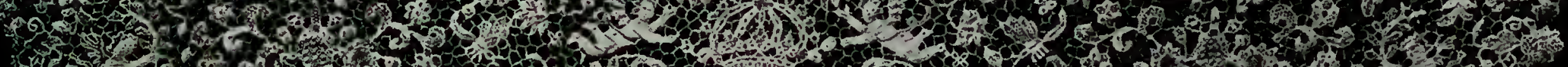
(x)

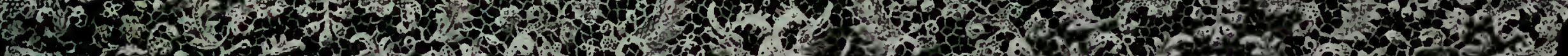

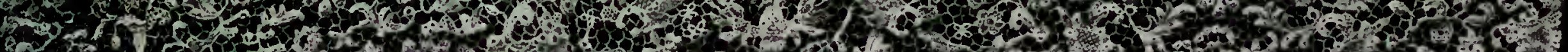

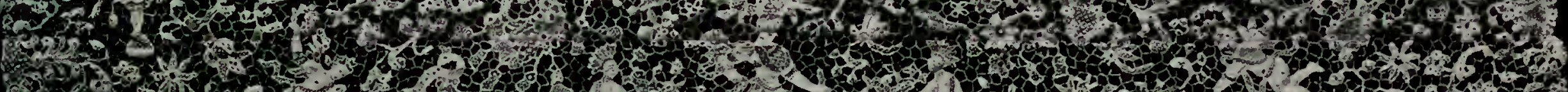

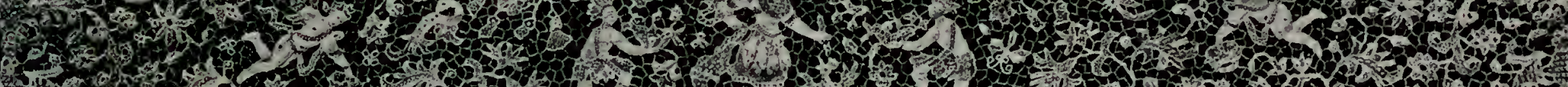

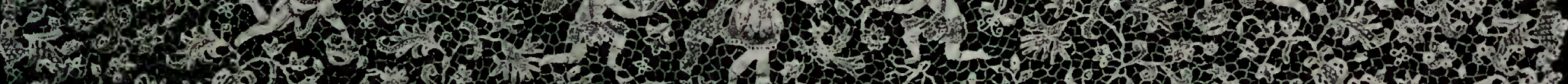

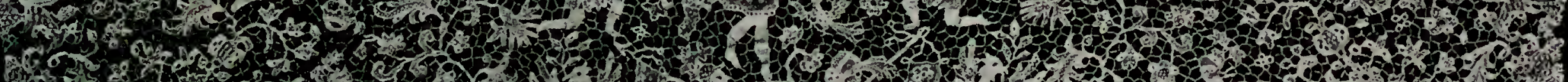

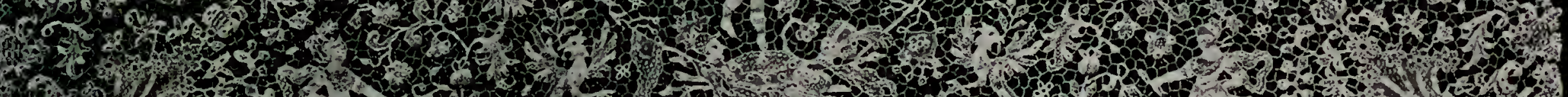

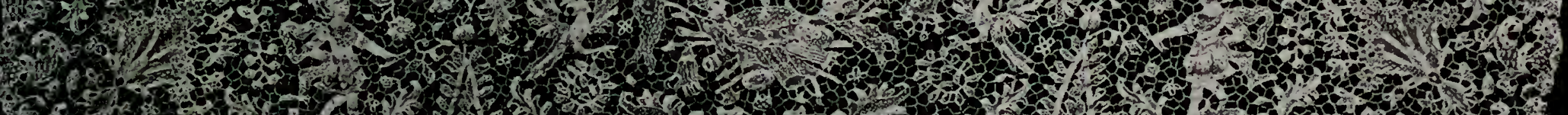

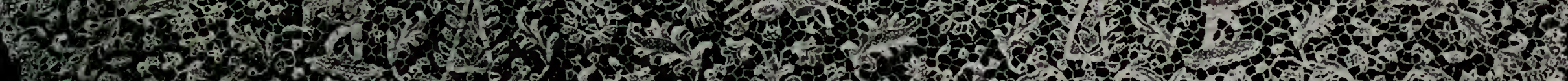

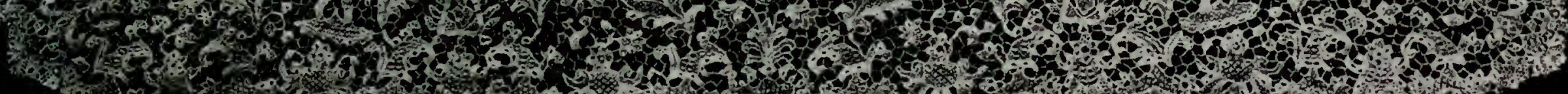

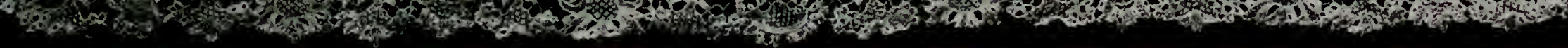

VIII. IABAT OF POINT DE FRANCE, WITH FIGURES, DOLPHINS, AND WARLIKE ATTRIBUTES

SECOND IIALF OW THE SEVENTEENTII CENTURY

COLLECTION OF MADAME PORGÈS 




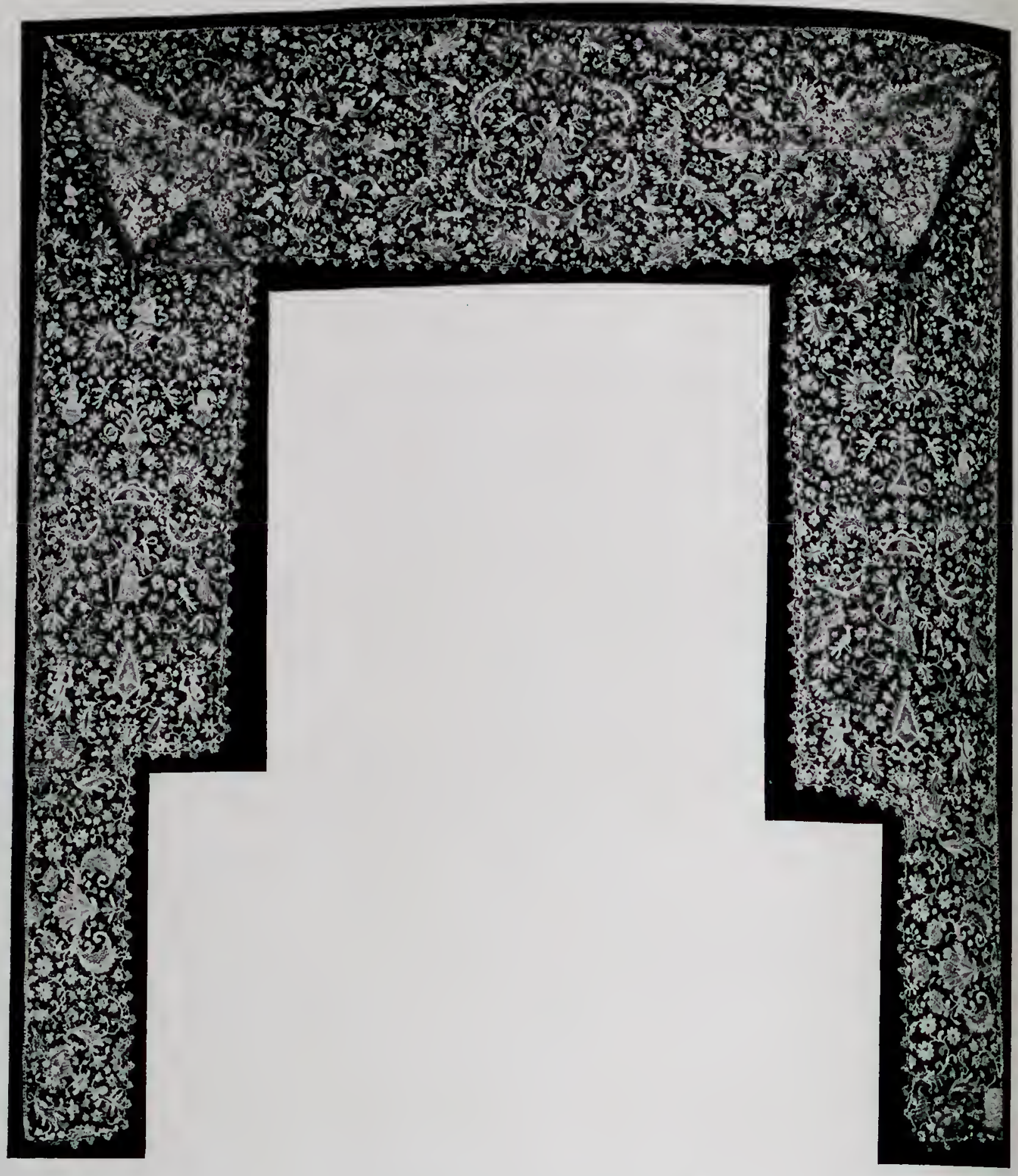

IX. BORDER OF POINT DE FRANCE SEVENTEENTII CENTURY

COLIECTION OF MADAME PORGÈS 
Bourgogne and the Duke of Anjou, dressed as young warriors.

From the same collection, the long piece of lace cut away at either end, must have been intended for a dressing-table. It is a fine specimen of the reign of Louis XIV. Again we find the dolphins, and as a central motive, several times repeated, a lady leaning on a long cane and fanning herself. Other figures, some half-length, some standing, carry baskets of fruit, and together with dogs and birds, move about in a background of flowers full of charm and poetry.

Three more splendid Points de France, of similar style and technique, were shown in the Retrospective Exhibition. In size they far surpass those which have been described, as they are deep flounces measuring more than 60 centimeters in depth, with a length of 3 meters, 3 o centimeters. These laces served as trimming for the rochets and albs of the prelates, the counterparts of which are seen in the portraits of Bossuet, Fénelon, and other bishops, painted by Hyacinthe Rigaud and Nattier. These deep flounces have not the figures and emblems of the laces intended for the use of the Princes of the Blood Royal.

The specimen belonging to the Abbé Bert is certainly designed in the same style as the beautiful medallion of the Sun in the Porgès Collection, with its vases of flowers surmounted by a canopy of garlands.

The rochet lent by Madame Lionel Normant is of a 


\section{[52]}

later date. Above are flaming hearts. The design is conceived in the same spirit as the beautiful marquetry of André Boulle, the ebonist of le Grand Roi.

The deep flounce in the Doistau Collection, though worked in the same manner as the preceding one, is of an inferior period. How different the design! It is true that one finds molives analogous to those of the Points de France which we have been sludying, but the composition is heavier, and it has lost that perfect elegance of the earlier laces, replacing it with the rocaille arrangement of a more questionable taste.

It is now the period of the Regency, in the beginning of the reign of Louis $X V$. The same heaviness of design is still more marked in the rabat of Point de France in the Cornély Collection ${ }^{1}$; whereas the flounce ra worked wilh bobbins, belonging to the Musée des Arts décoratifs, retains the lightness and the distinction of the period of Louis XV. To this heavy style can be at tributed the specimen in the Porgès Collection, and also two others with an entirely different grounding of openwork.

We come next to the style of the Rococo, when the influence of Queen Marie Leczinska is felt, Chinese motives being dominant in many designs. Madame

1 Now in the Musée des Arts décoratifs. It is there called Point de Sedan, on account of the occasional accentuations of relief, believed to be characteristic of that city, to which are also attributed the bas de rochets of large flowered designs, with the grande bride picotée grounding of the Point de France. Note by the Translator. 



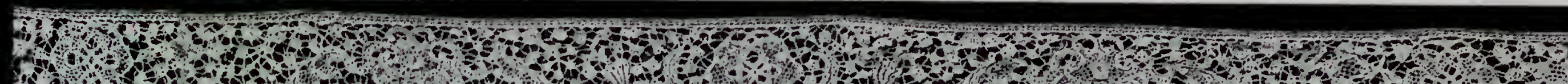

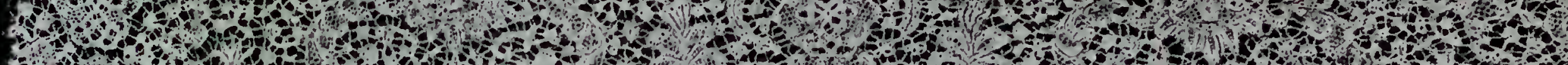

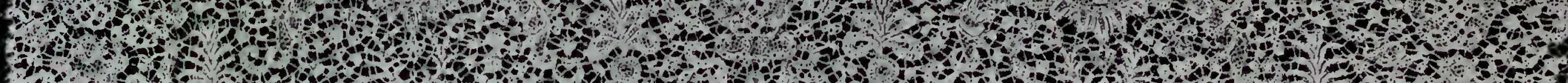

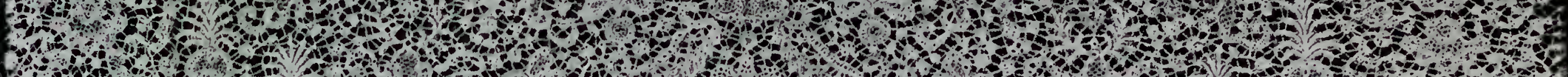

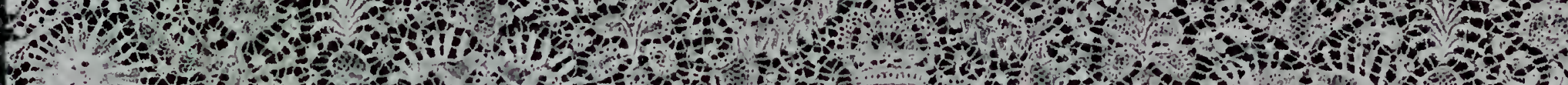

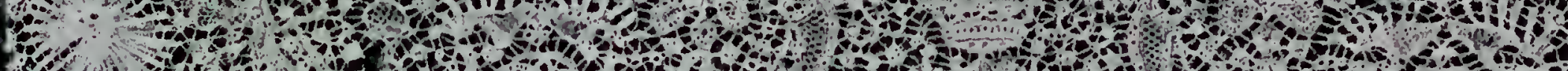

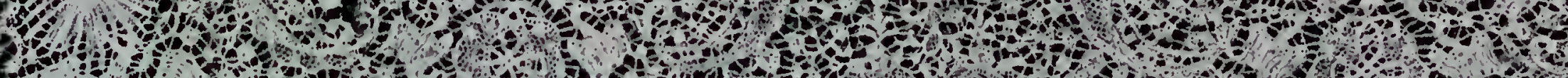

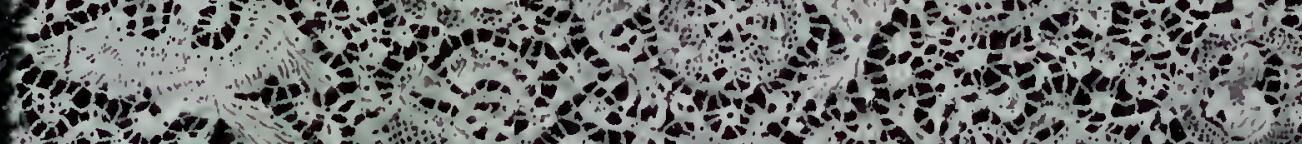

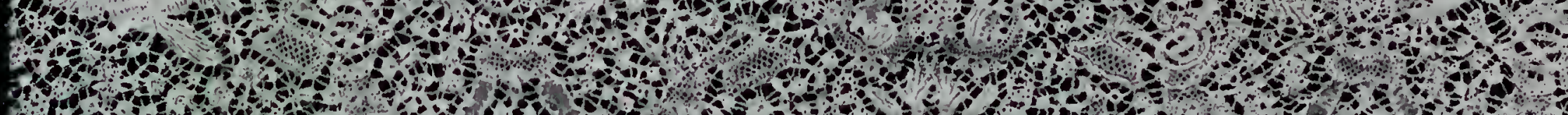

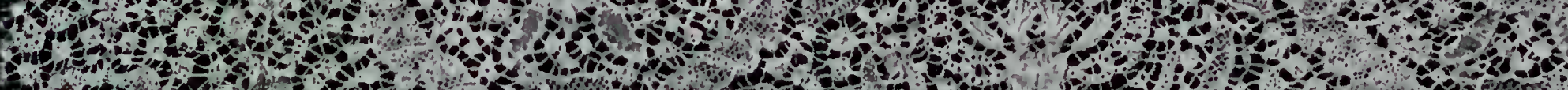

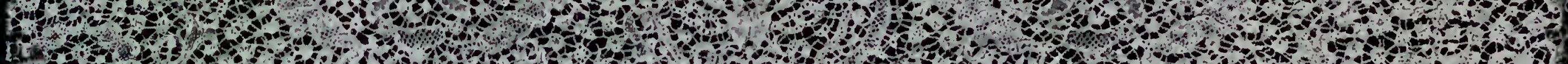

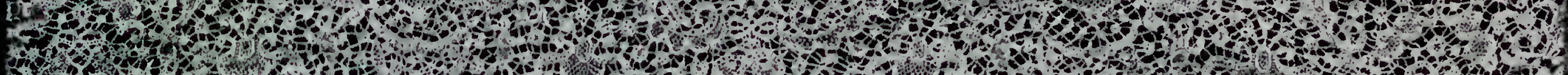

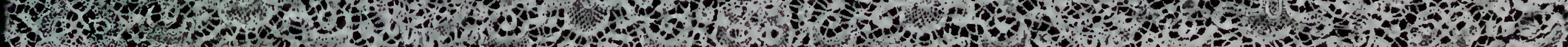

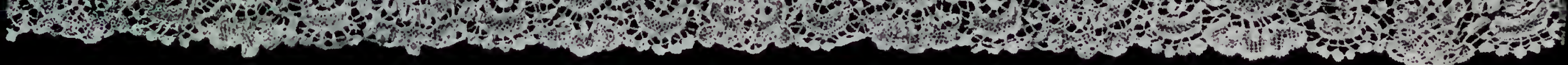




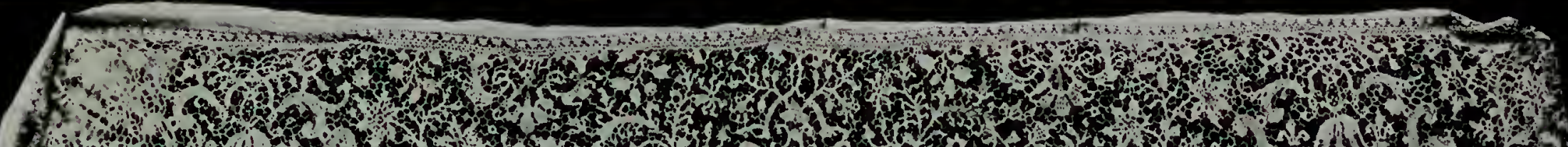

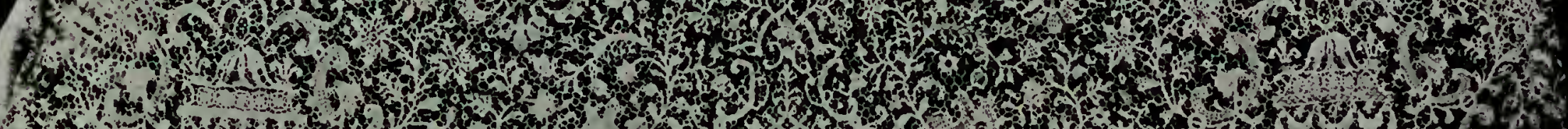

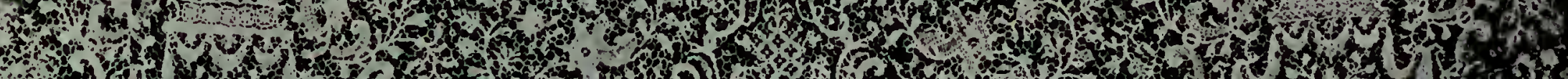
$\begin{aligned} 2 & \end{aligned}$

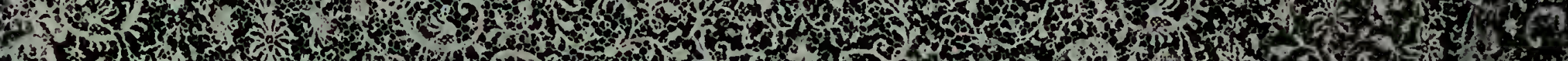
5 .

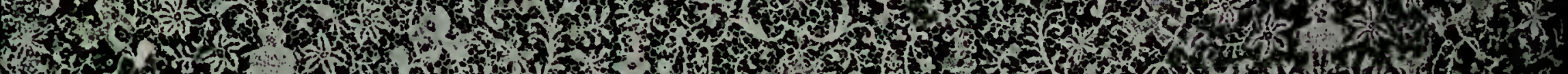

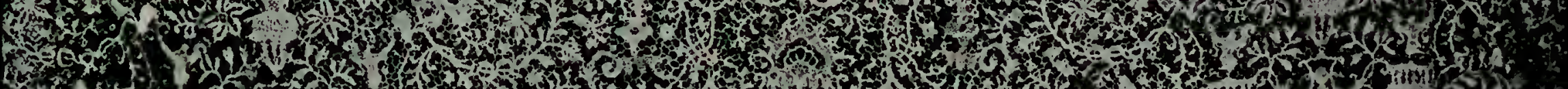

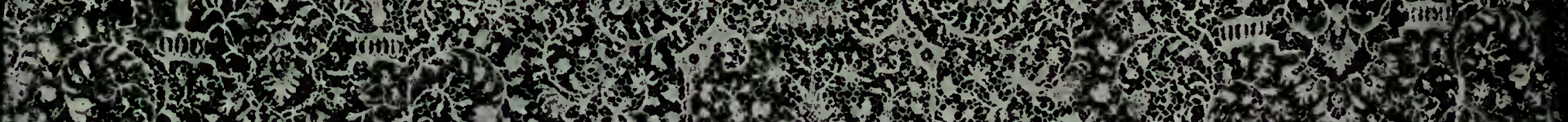

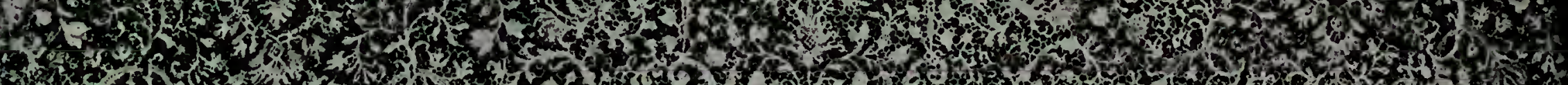

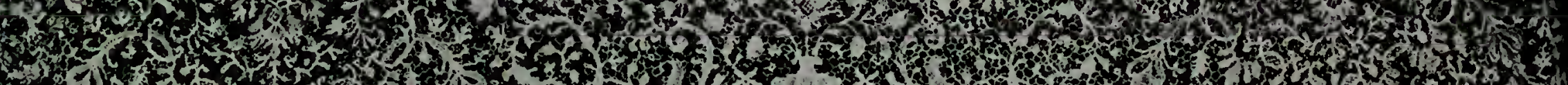

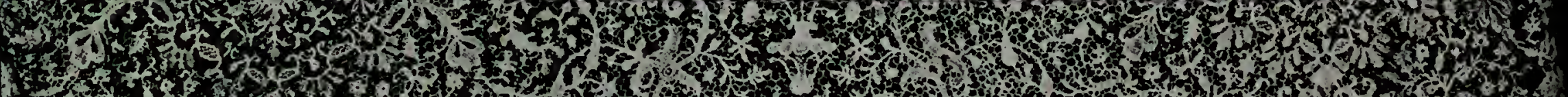

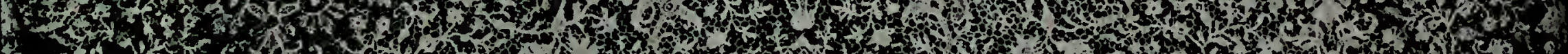

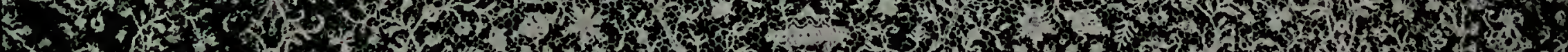

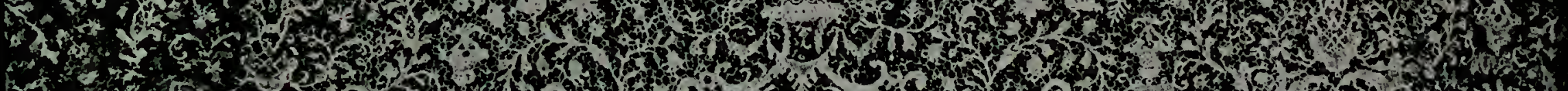
b.

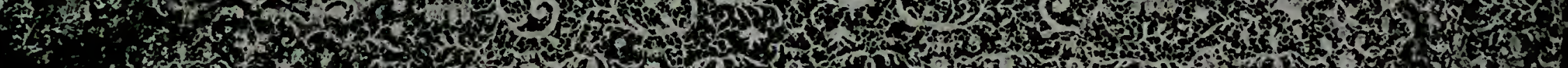

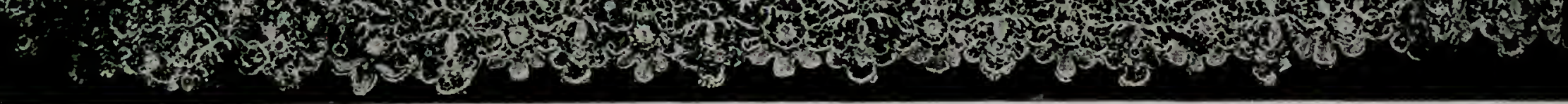

XI, DEEP IBORDER FOR AN ALB OF POINT DE FRANCE 




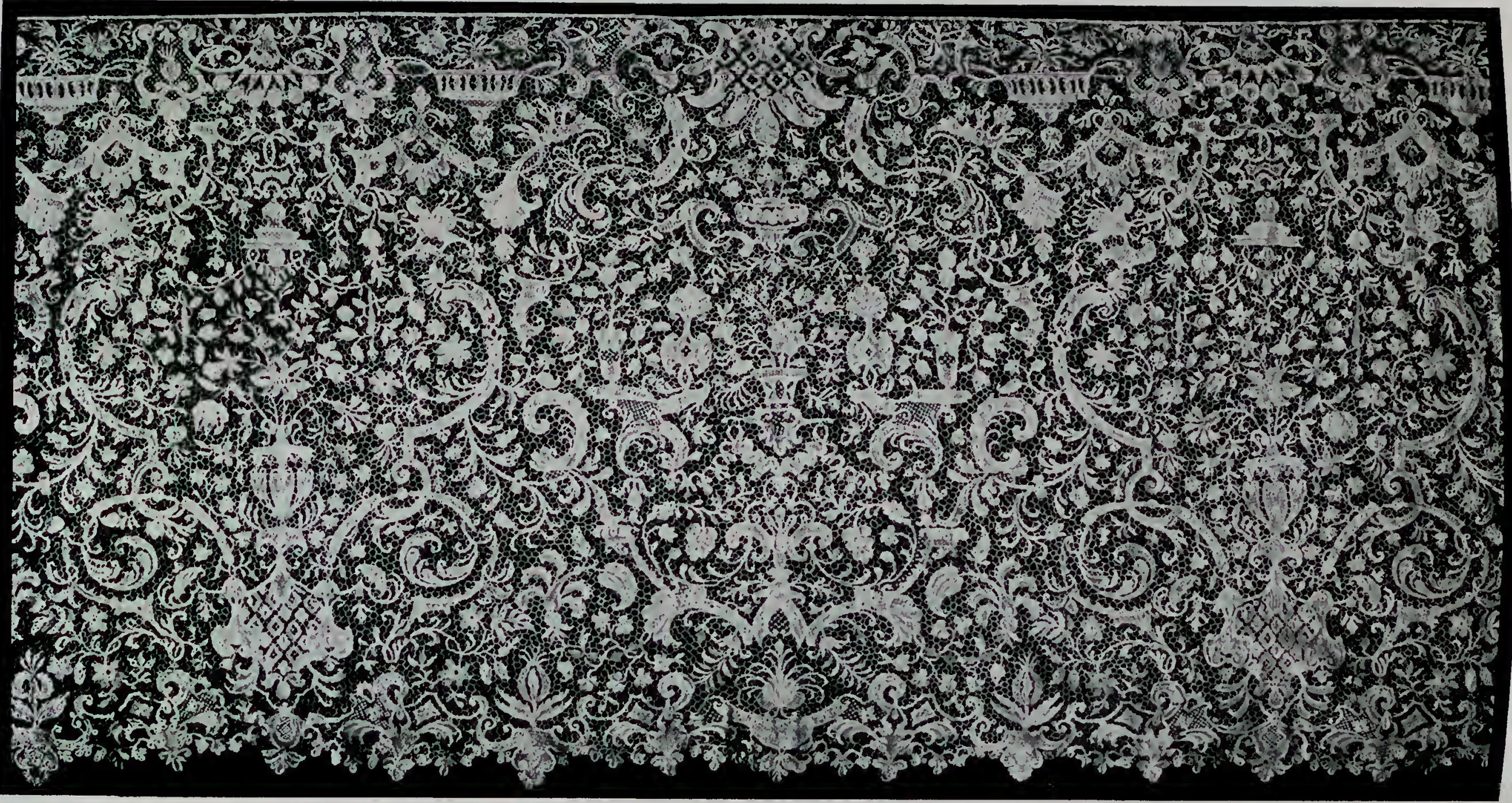




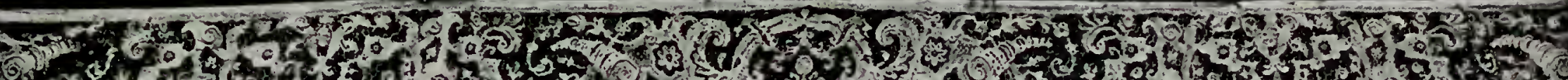
3. 3.

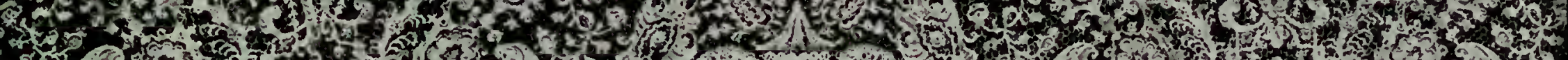

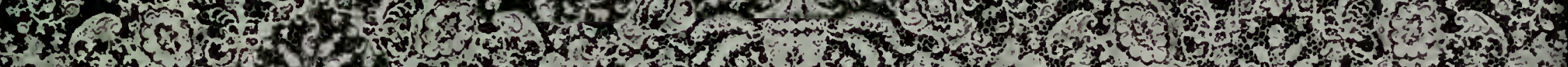

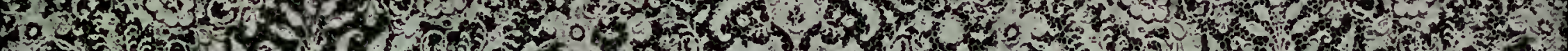

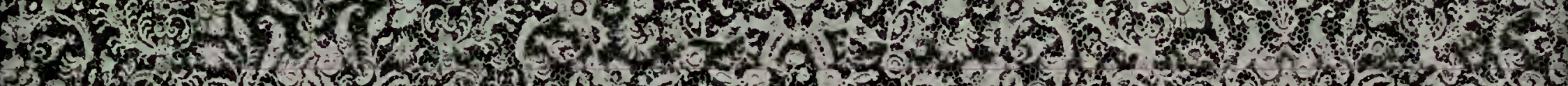

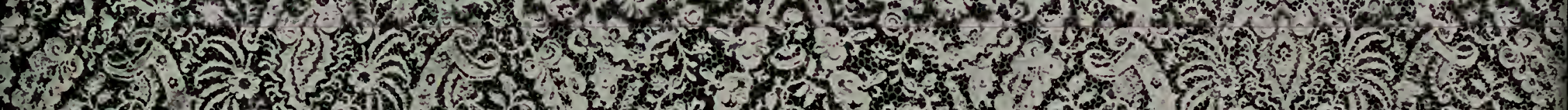

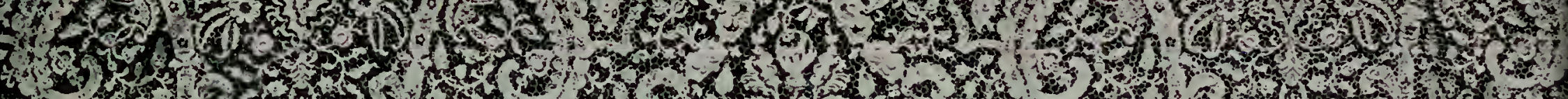

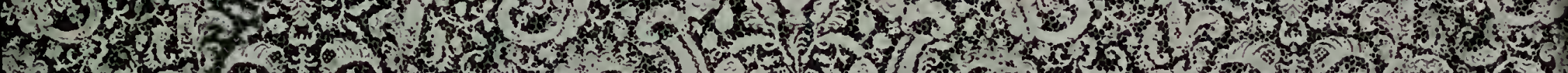

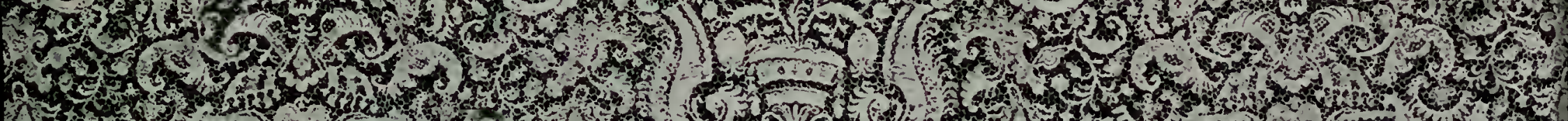

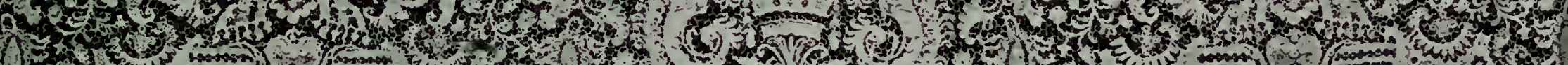

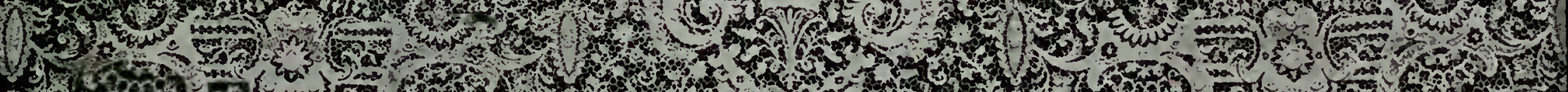

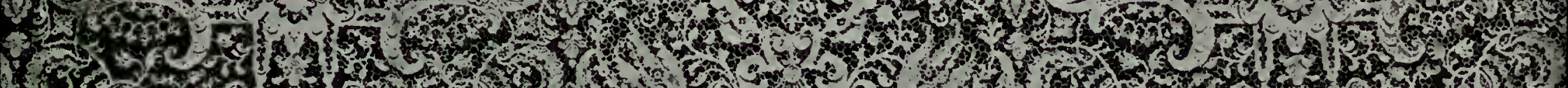

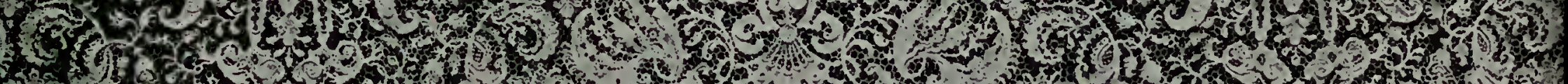

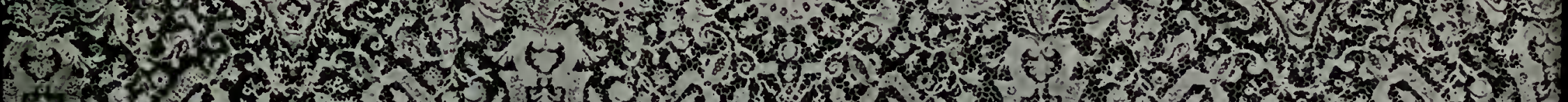

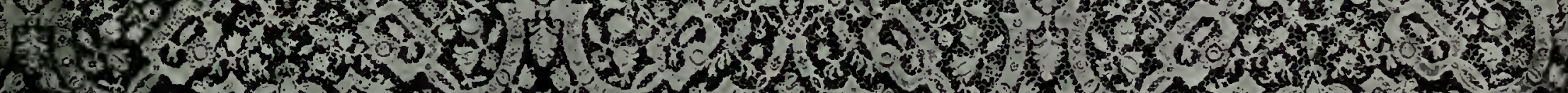

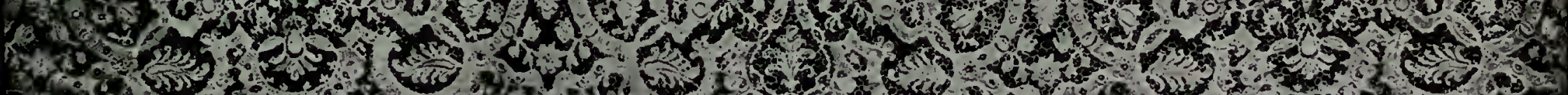

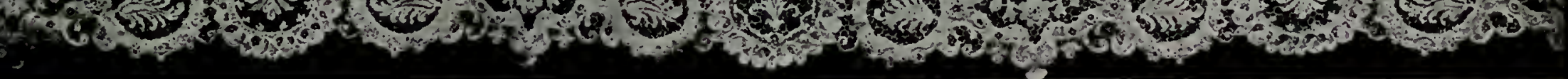






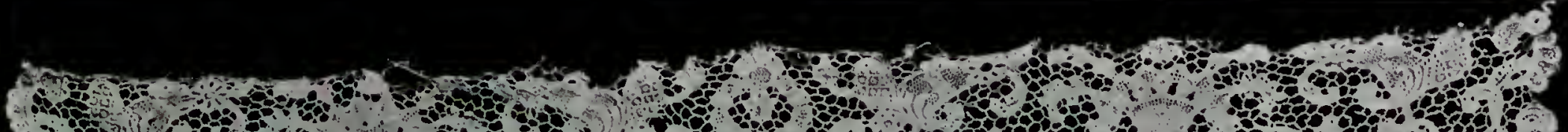

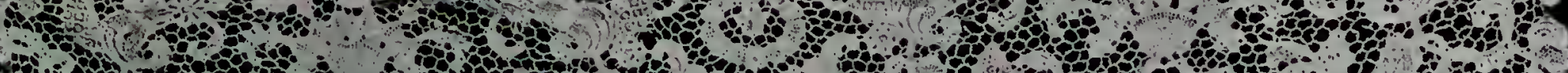

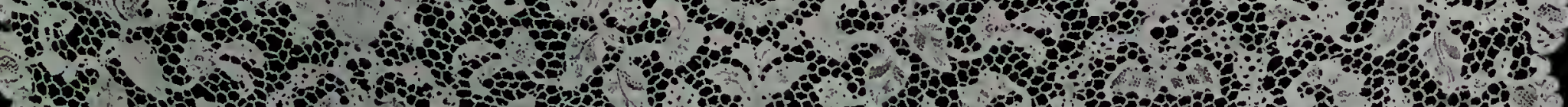

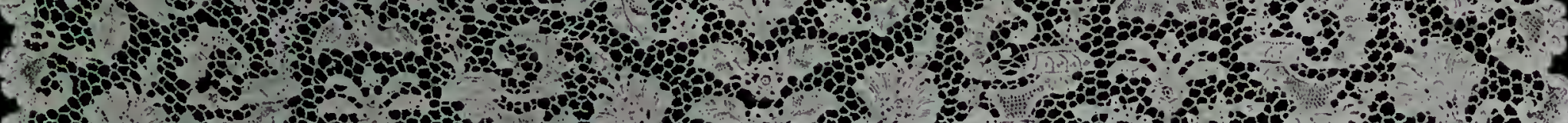

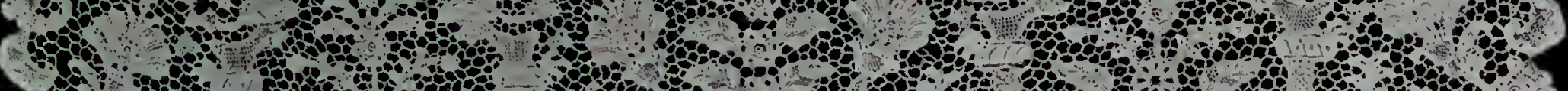
2.

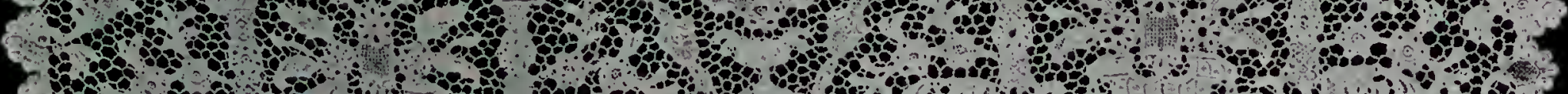

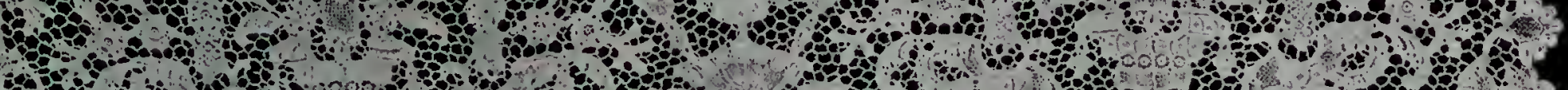
20
3

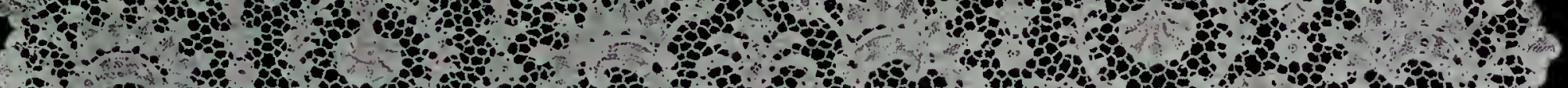

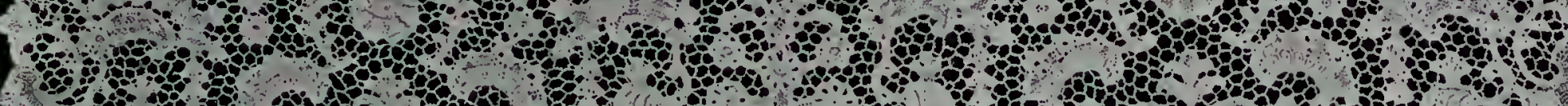

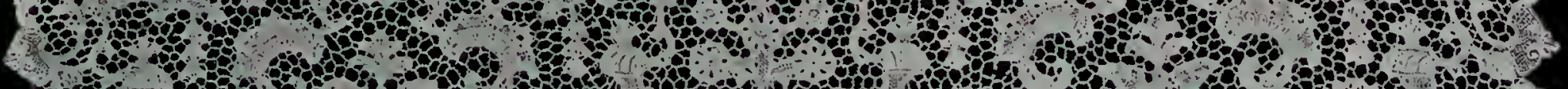

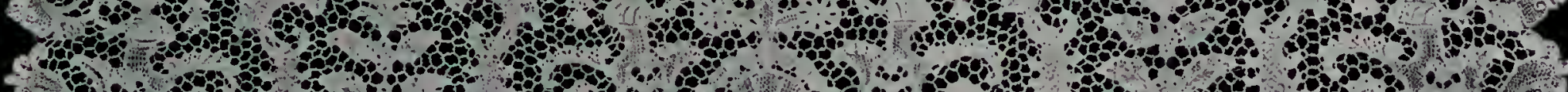

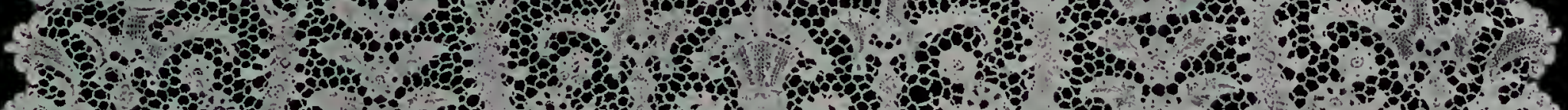

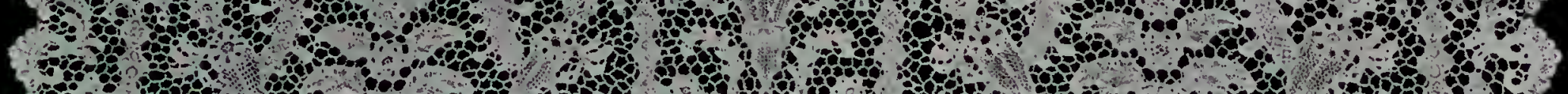

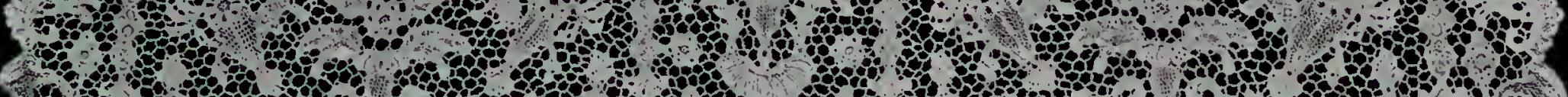

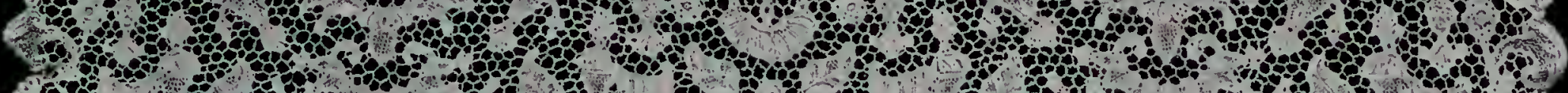

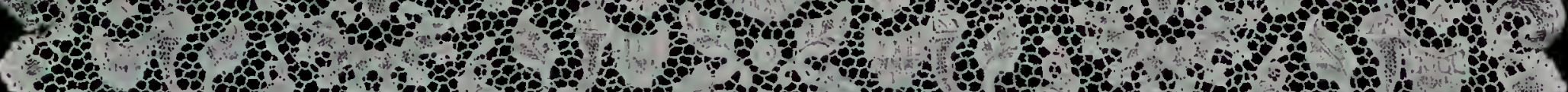

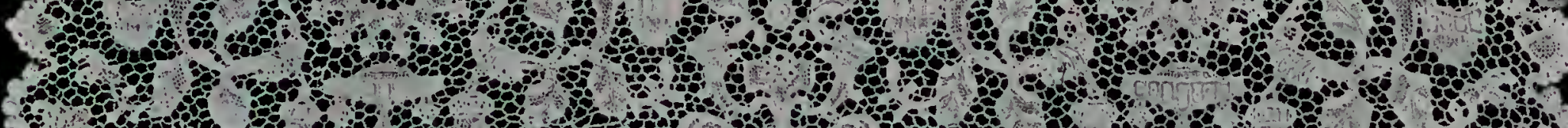

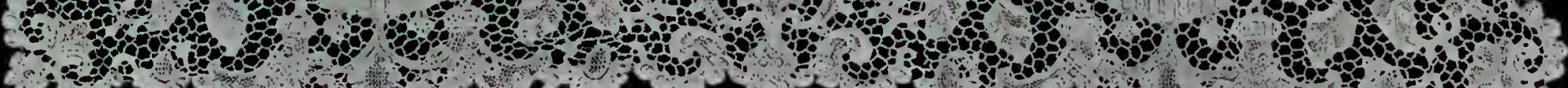
$60-30$ - 
W.

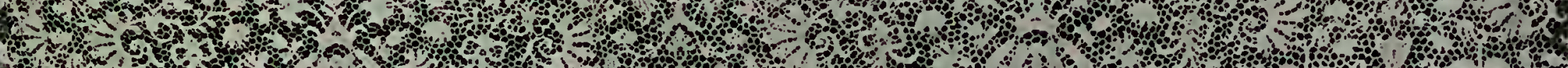

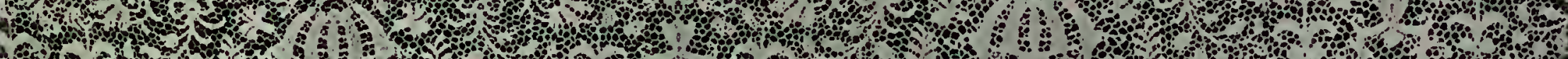

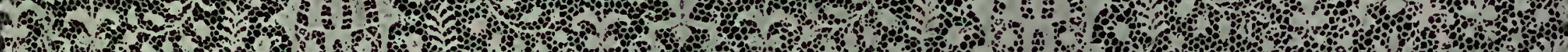

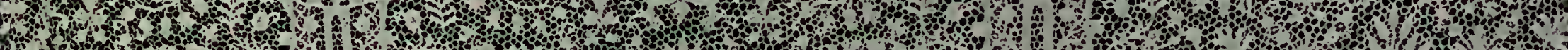

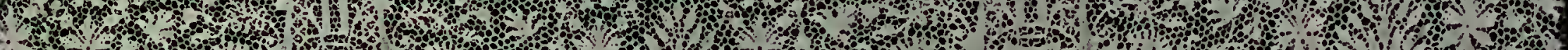

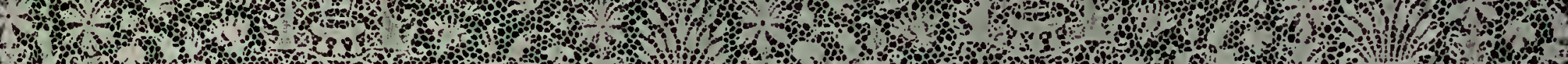

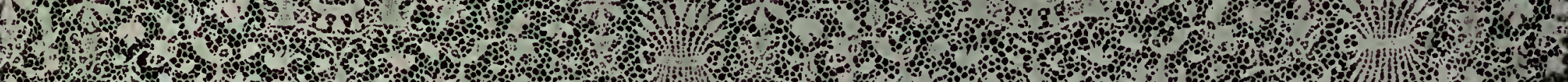
3.

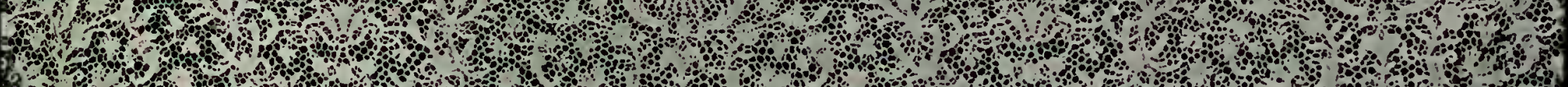

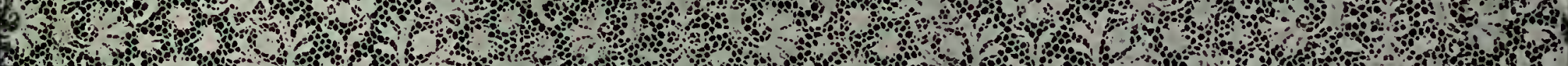
$F_{1}$

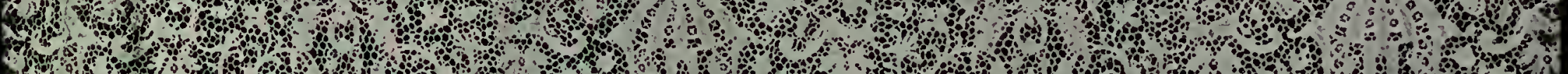

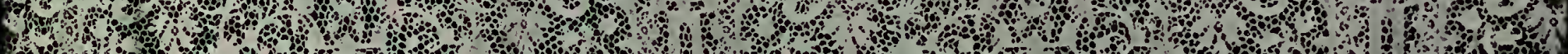
W. 6.0.

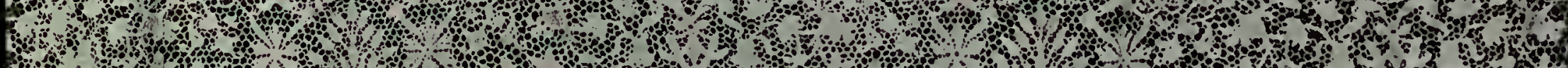

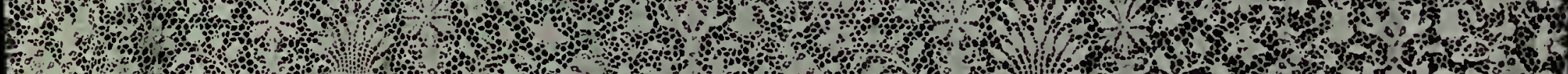

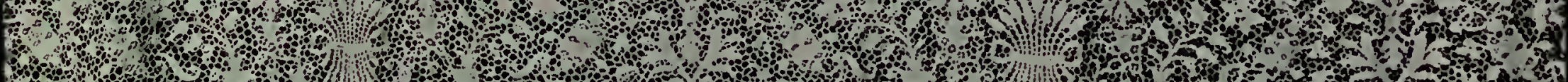

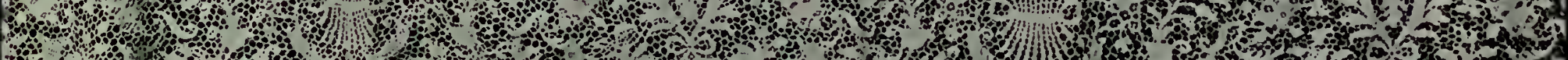

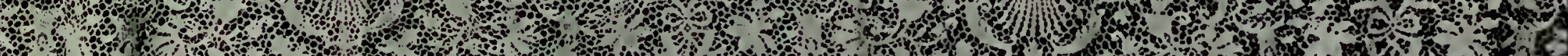

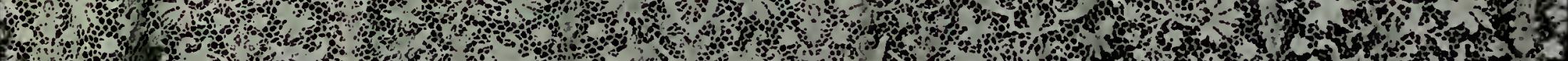

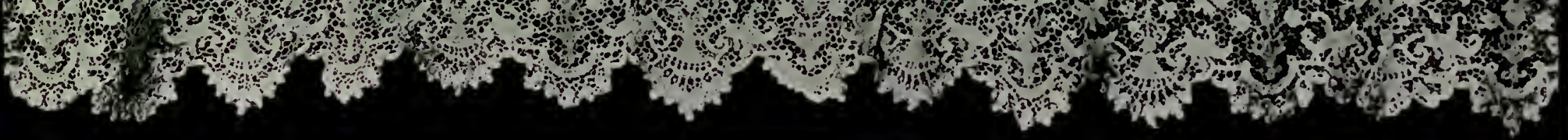

XV. DEEP FLOUNCE. PEIIOD OF THE REGENCT. FIRST MALF OF THE EIGHTEENTI CENTURY METROPOLITAN MUSEUM OF ART 

Jut

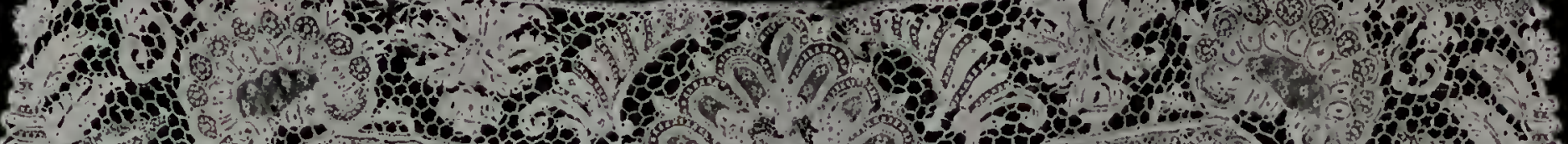

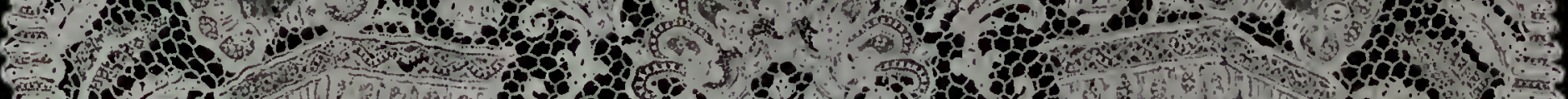

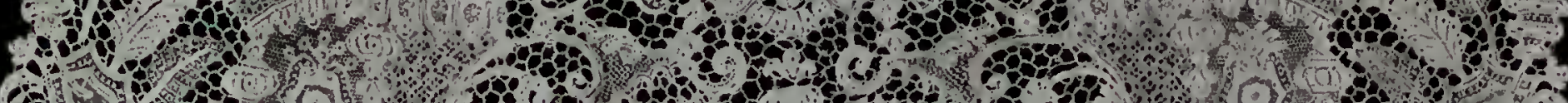

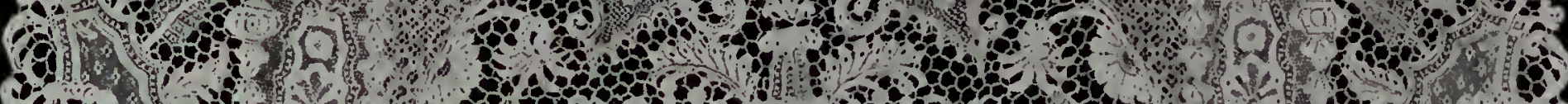

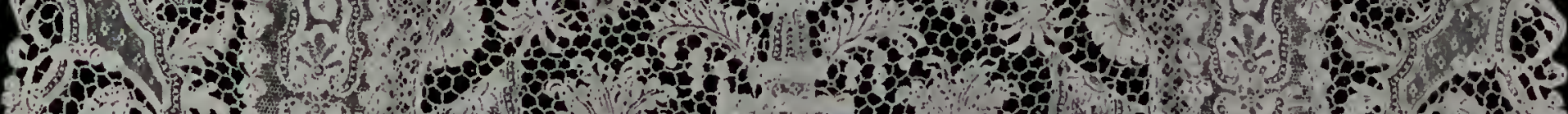

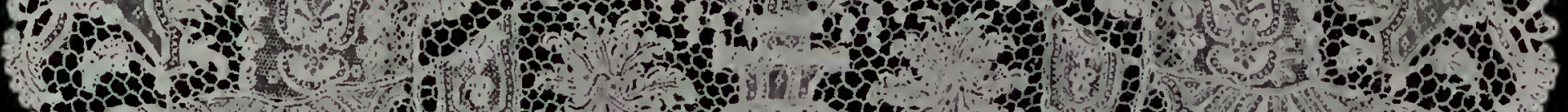

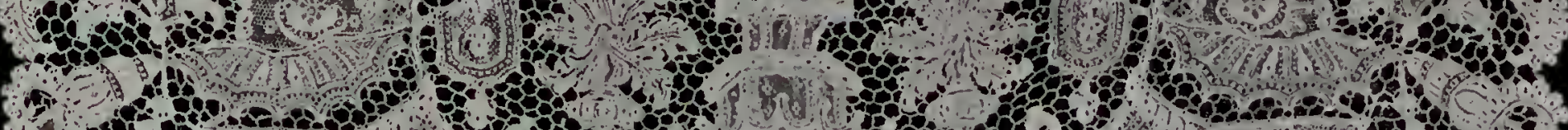

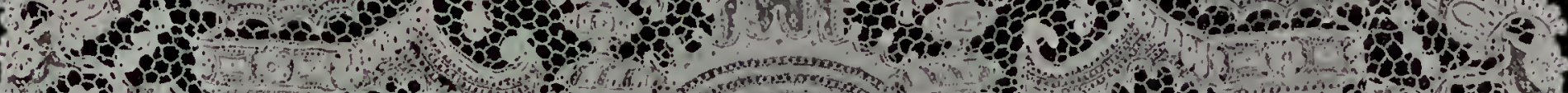

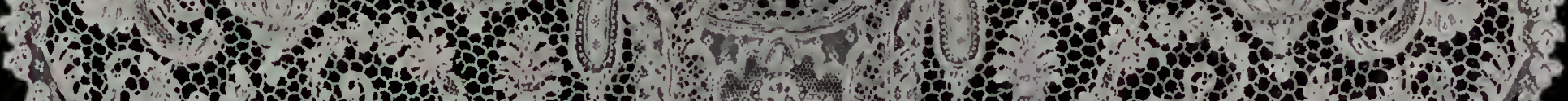

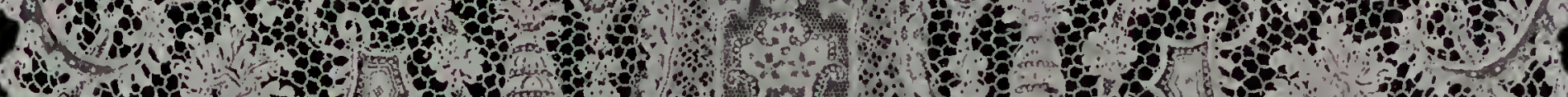

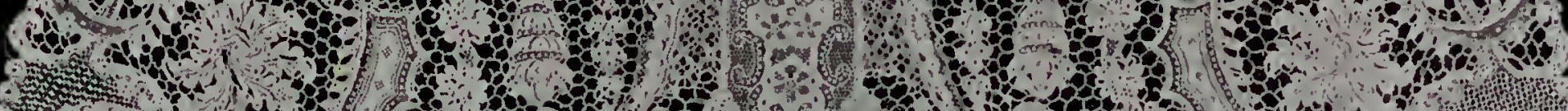

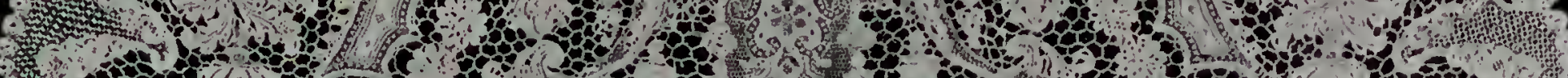

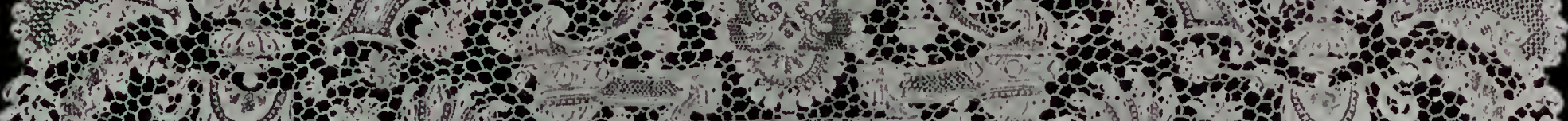

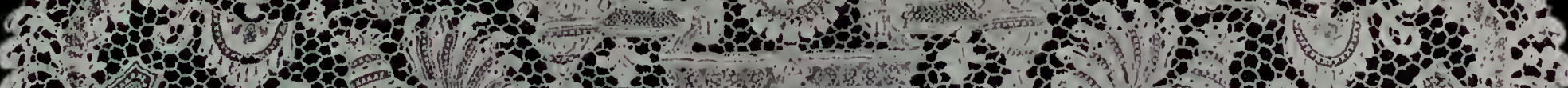

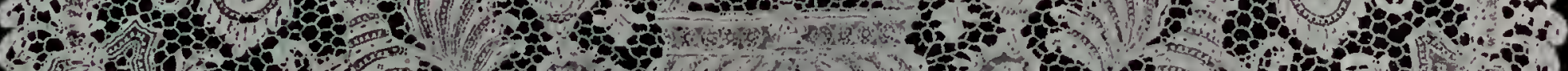

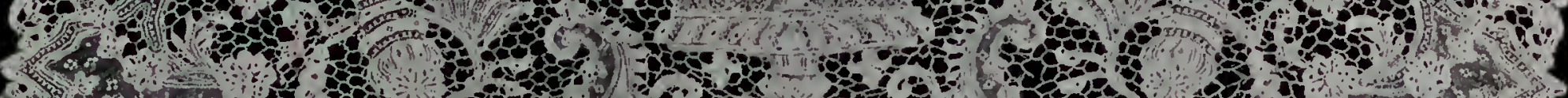
2.

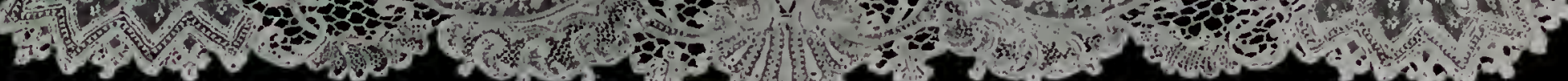




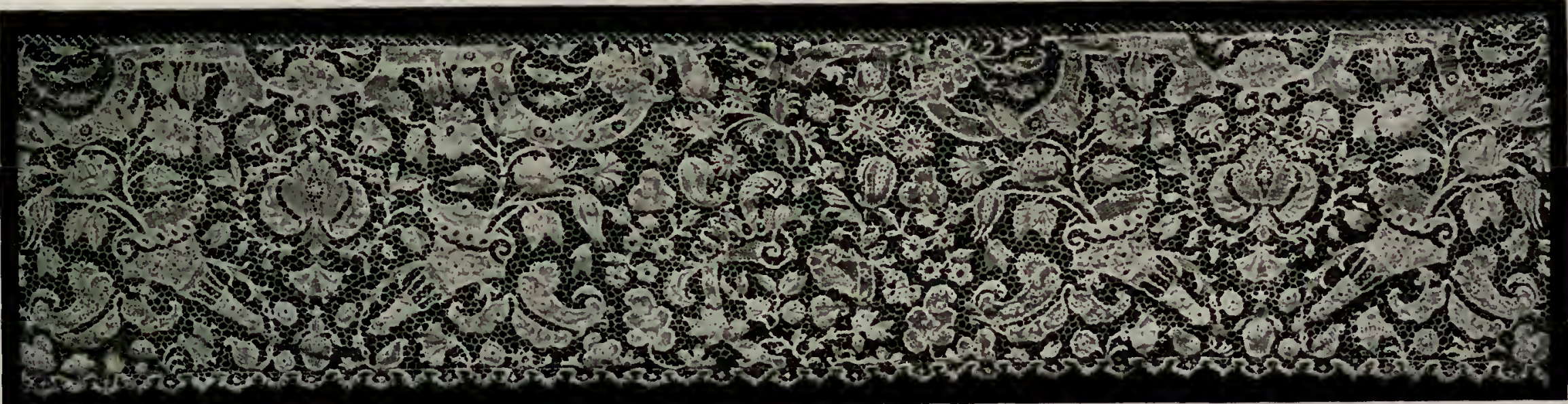

XVII. POINT DE FRANCE. PERIOD OF THE IREGENCI 




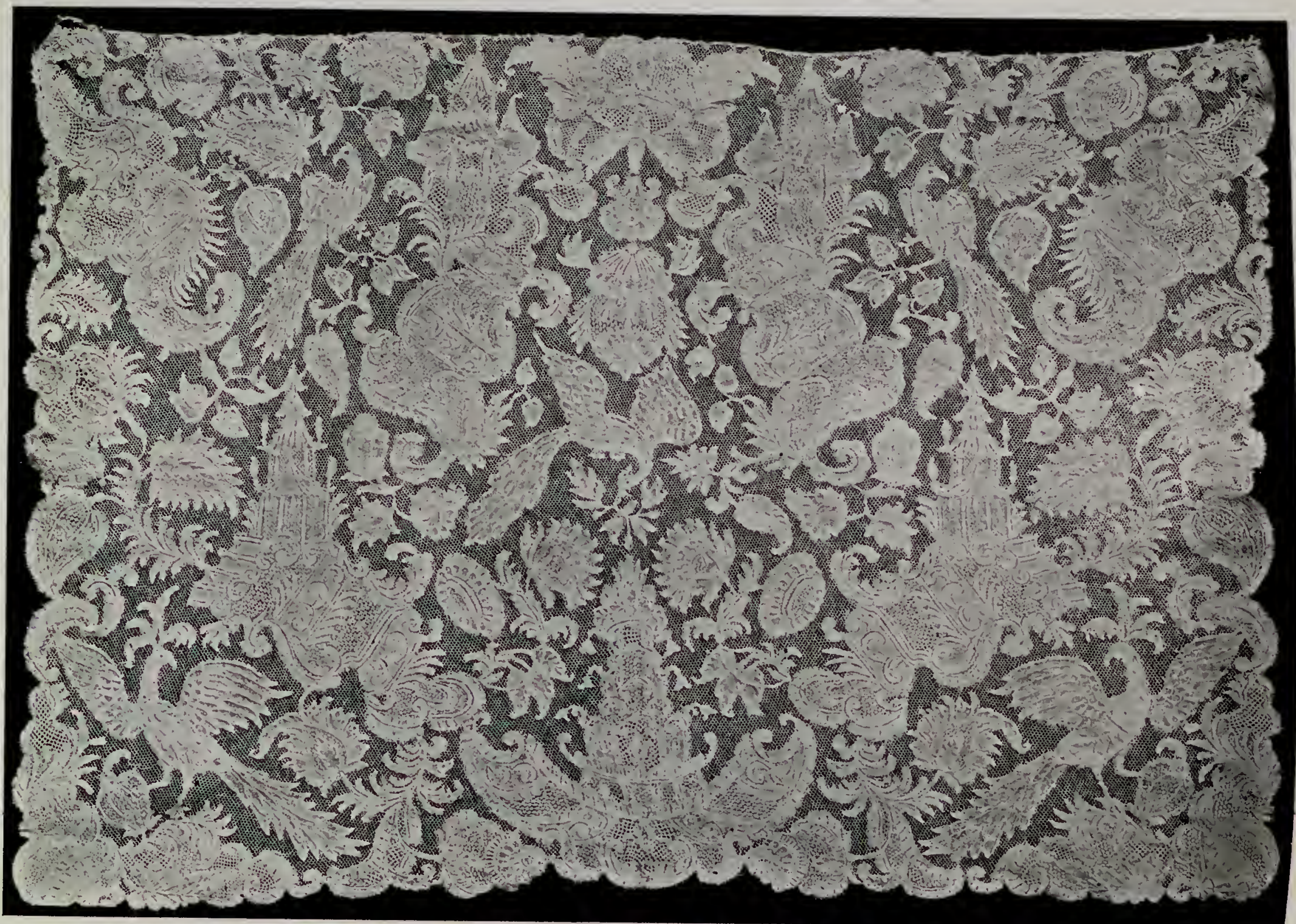

XVIIT. TRABAT OF BOBRIN-TANR. DESTGN OF PEACOCKS ANDPAGODAG. PERIOD OF I.OUIS XV COLLECTION OF MADAMT DOISTAU 
XIX. BERTIA. NEEDLE-TOINT

DESIGN OF IIUNTSMEN AND OTHER MOTIVES

IN TIE STYLE OF DRESDEN CIINA

PERIOD OF LOUIS $X \mathrm{~V}$

COLLECTION OF MADAME IAA COMTESSE FOI

$7 \%$,

(6) $\Rightarrow,-1,1$

$-\sin x$

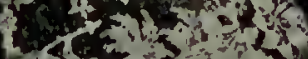

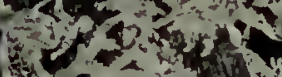

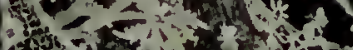

of

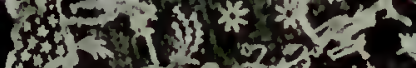

6 (1)

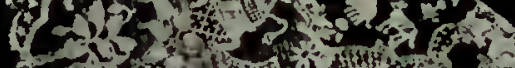

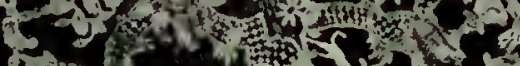

He.

in

$2 x$ i $2 x$

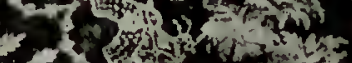

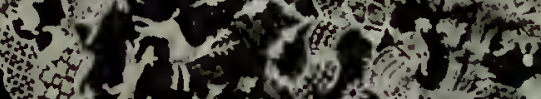

a

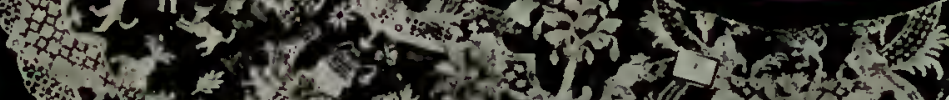

(3)

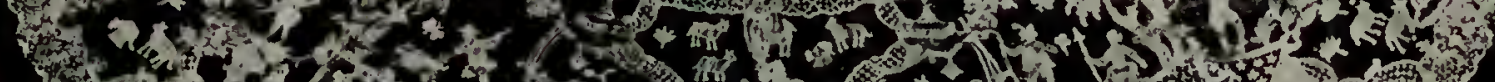

(1)

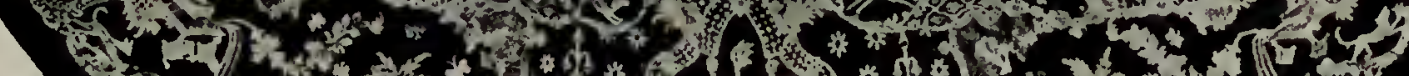

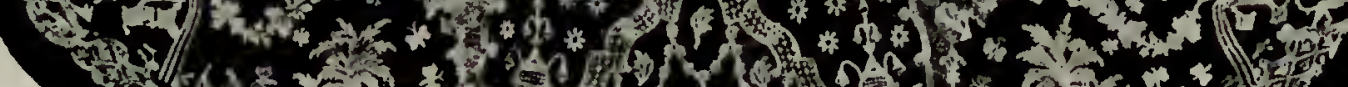
-

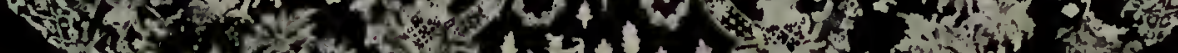

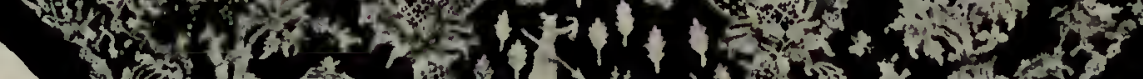

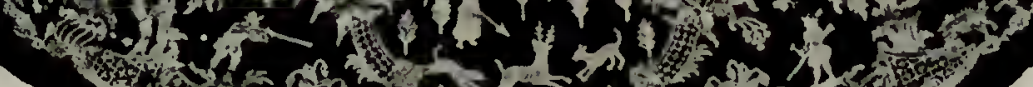

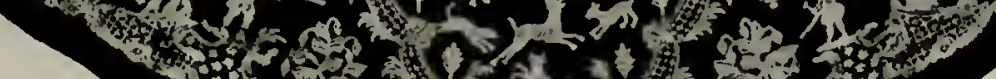

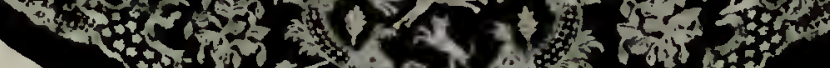
-

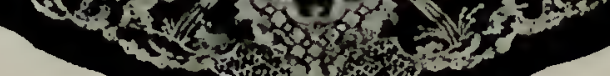





\section{$[73]$}

Doistau and Madame la comtesse Foy lent two pieces of lace of this style, which, though of Flemish origin, were still shown in the Retrospective Exhibition. The first is a square rabat worked with bobbins, in which are pagodas surrounded by peacocks perched on flowering plants, the foliage resembling the leaves of palmtrees. In the second we find to how great an extent old Dresden china is still in style. The designs of lace thus inspired have little kiosks and miniature landscapes with rocks and rivers, and dogs and huntsmen pursue the small deer. A similar influence is felt in the bertha so delicately executed in needle-point stitches.

Queen Marie Antoinette, in the beginning of her reign, gave a special impetus to the production of lace. She liked flowers, the tulip and the pink, but above all others she loved the rose, which is everywhere seen in garlands entwined with ribbons. The Retrospective Exhibition showed a fine specimen of these laces in the deep flounce of Point d'Argentan, lent by Madame Verdé-Delisle. The lace of this period has often been reproduced, but the copies have lacked the special grace of this authentic specimen of a style the most charmingly feminine which has ever been produced.

The French laces, we thus find, were much esteemed; as proof of this can be cited an unpublished document in the library of the learned Courajod, who died some years ago. It is a report on the commerce of France with foreign countries in the year 1773 . 


\section{$[74]$}

(Archives of M. F. Carnot.) The importations of lace into France amounted to the sum of 433,470 livres, the greater part of which, 399,600 livres, came from Flanders. The exportations reached a total of $3,732,-$ io3 livres, the greater number of which, $1,176,536$ livres, went to England.

The laces exported were point-lace from Alençon and Argentan (which cities laid claim to working the Royal Point ${ }^{1}$ ), Valenciennes, Chantilly, both white and black, Point de Paris, guipures, and thread lace from Le Puy, where also laces of gold and silver thread were made. The exports from Le Puy were packed in cases of four or six boxes, each box containing one hundred pieces of the length of iwelve aunes, assorted according to the demand, and ranging in price from 300 to 1200 livres. A great number of cases were shipped at Havre and at Cadiz for the Spanish West Indies. Many capes and lappets for head-dresses were included in these sales.

The Retrospective Exhibition showed many small pieces of lace, barbes, or backs of caps, of the period of Louis XVI.

\footnotetext{
1 Madame Despierres, in LE: Pornt d'Alençon, says that the name Point de France should be used only for the laces produced during the ten years of the Royal Monopoly, I665-I6-5 A.D., but we find it in many of the interesting documents which she cites far on in to the middle of the next century. Many more documents have been recently published in LE POIxCT DE France, by Madame de Laprade. Note by the Translator.
} 



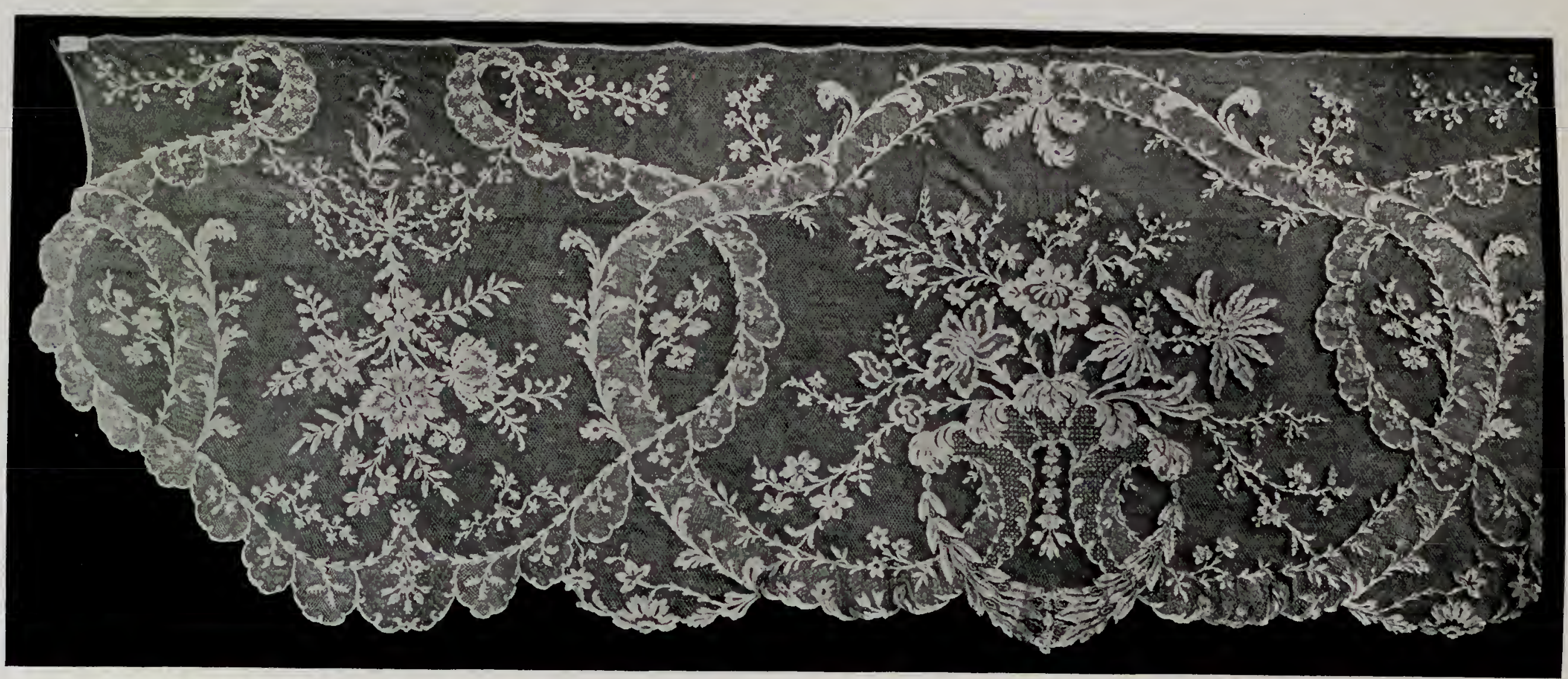

XX. FLOUNCE OF POINT D'ARGENTAN. STYIE OF LOUIS XV. MIDDLE OF THE EIGHTEENTH CENTURY MUSÉE DES ARTS DÉCORATIFS 


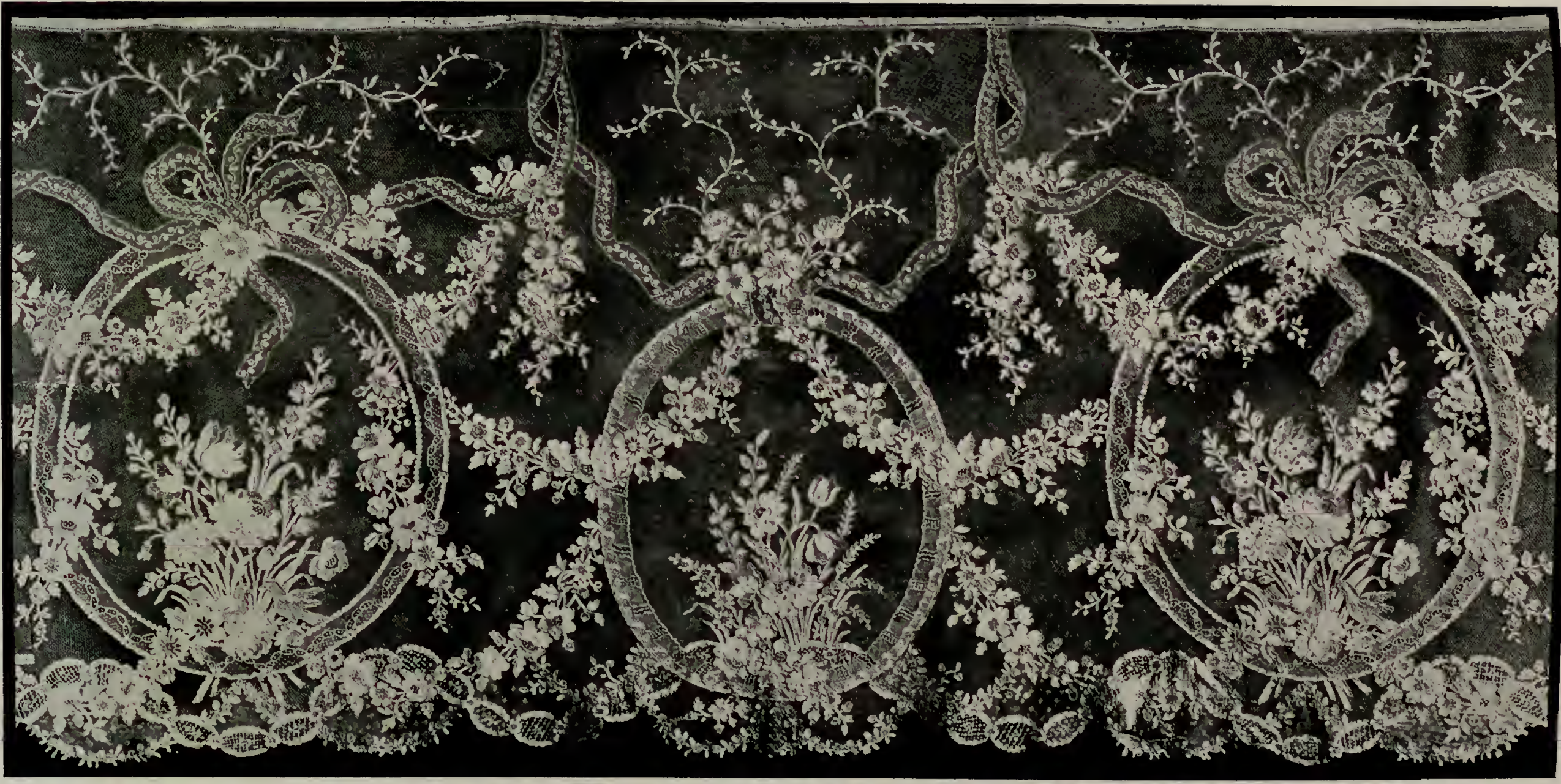

XXI. FLOUNOE OF POINT D'ARGENTAN. STYLE OF LOUIS XTI LATTER HALF OF THE EIGHTEENTH CENTURY

MUSÉE DE LA CHAMBIE DE COMMERCE DE LYON 



$$
\text { [ } 79]
$$

At the approach of the Revolution, this prosperous industry ceased. During the last years of her life, disquieted by the menacing nature of the passing events, Marie Antoinette wore none but the simplest raiment - dotted muslins - linen trimmed with lace, covered with dots and flowers, and finished with a narrow border. As the shadows darkened, both the linen and the dresses of the Queen were trimmed with marly, a narrow edging covered with dots or point d'esprit, and edged with a narrow feston. 


\section{Chapter III}




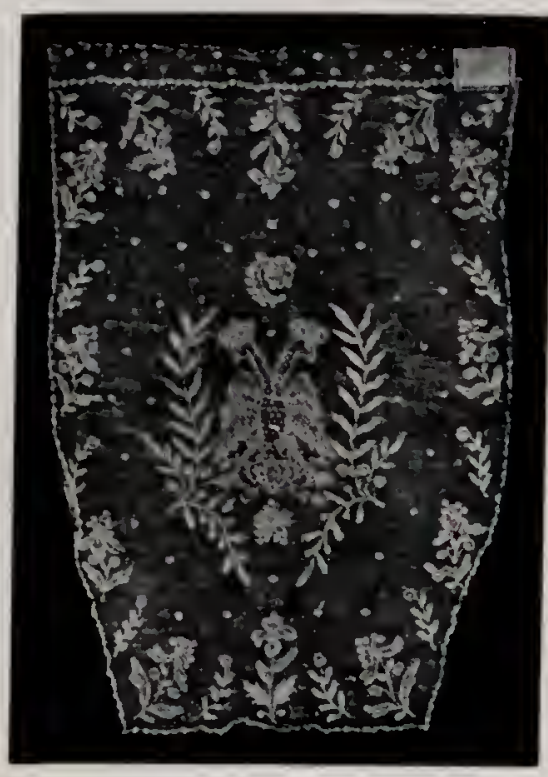

XXII. STOMACHER. FIRST EMPIRE

COLIECTION OF MADAME PORGES 


\section{Chapter III}

Lace from the Revolution to our own day

AfTer the Revolution came the Directory, when David's influence was supreme in the world of art, and his style, which drew its inspiration from Roman art, is also found in the designs of lace. The stiffness and dryness of the lines imitate the antique in a pretentious manner, which is wholly lacking in freedom.

Under the Empire, we find at first laces having only a light semé (powder) of dots and leaves. The roseleaf and the tulip are now replaced by leaves of olive and laurel, and soon the Imperial bee ${ }^{1}$ replaces the fleur-de-lis. Nobles of recent date and the Noblesse de l'Épée deck themselves with their escutcheons at the fètes given by Napoleon I. This we find in thetwo stomachers lent by Madame Porgès. The Imperial Court strives to reproduce the luxurious effect of its most brilliant period; everywhere are garlands and draperies drawn together with cords and tassels entwined with flowers, which show their date. Branches of oak and laurel, allied to the rose of La Malmaison,

\footnotetext{
1 The bee of Napoleon is laid flat upon the grounding, whereas the form seen in the late eighteenth century is in profile. Note by the Translator.
} 


\section{[ 86$]$}

distinguish the laces destined for the wives of the dignitaries of the new chivalry - the Legion of Honor.

A very beautiful flounce in the collection of Madame Casimir-Périer was one of the most admired laces at the Retrospective Exhibition, for richness of design and the admirable quality of work.

Under the Restoration, they sought to revive the traditions of Marie Antoinette, but through the years of the Revolution, and of the Empire, that special note of elegance which characterized the period of Louis XVI had been lost. The laces of the Restoration have a large semé of even motives, with flowered borders, wholly lacking in freedom or charm of line. The fleurs-de-lis are more rounded, and the roses, no longer studied from nature, seem stiff and heavy compared to those of the preceding century.

A curious engraving of this time (Musée Carnavalet) is a prospectus of the Fabrique de Chantilly, Oise, Industrie française (sic), which shows that dresses of blonde were then made, trimmed with three flounces, and also caps, scarfs, and lappets, as worn by the seated lady in the accompanying illustration. In the background there is also a shawl, with a bunch of flowers in the center and a border of roses, folded in such a way as to fall in double rows, as was the custom of the time. The wide gulf which separates the taste of the period of Louis XVI from that of the Restoration is 


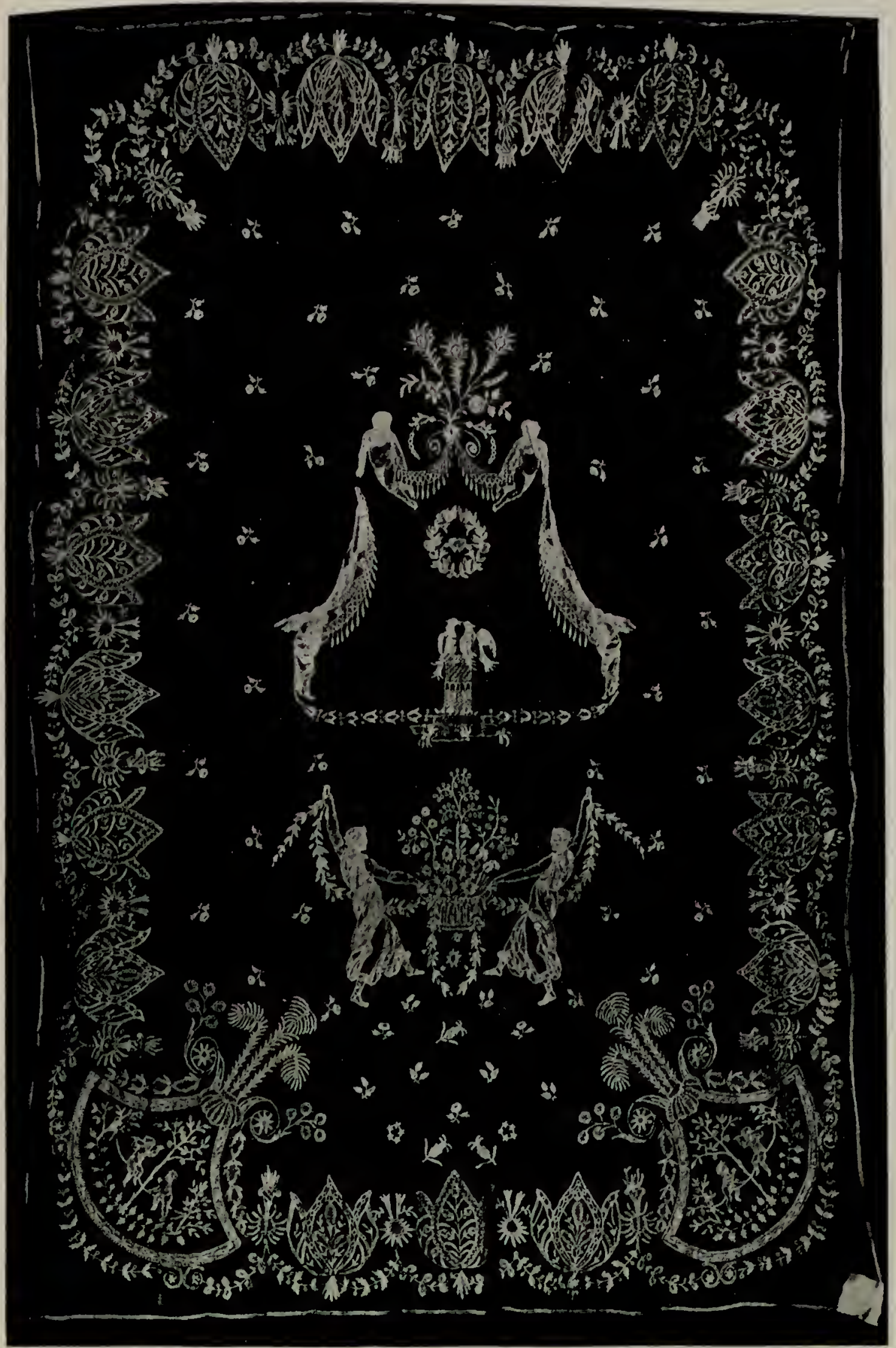

XXIV. BEDSPREAD FROM LA MALMAISON

FROM A PHOTOGRAPH

IN THE LIBRARY OF THE MUSEE DES ARTS DÉCORATIFS 


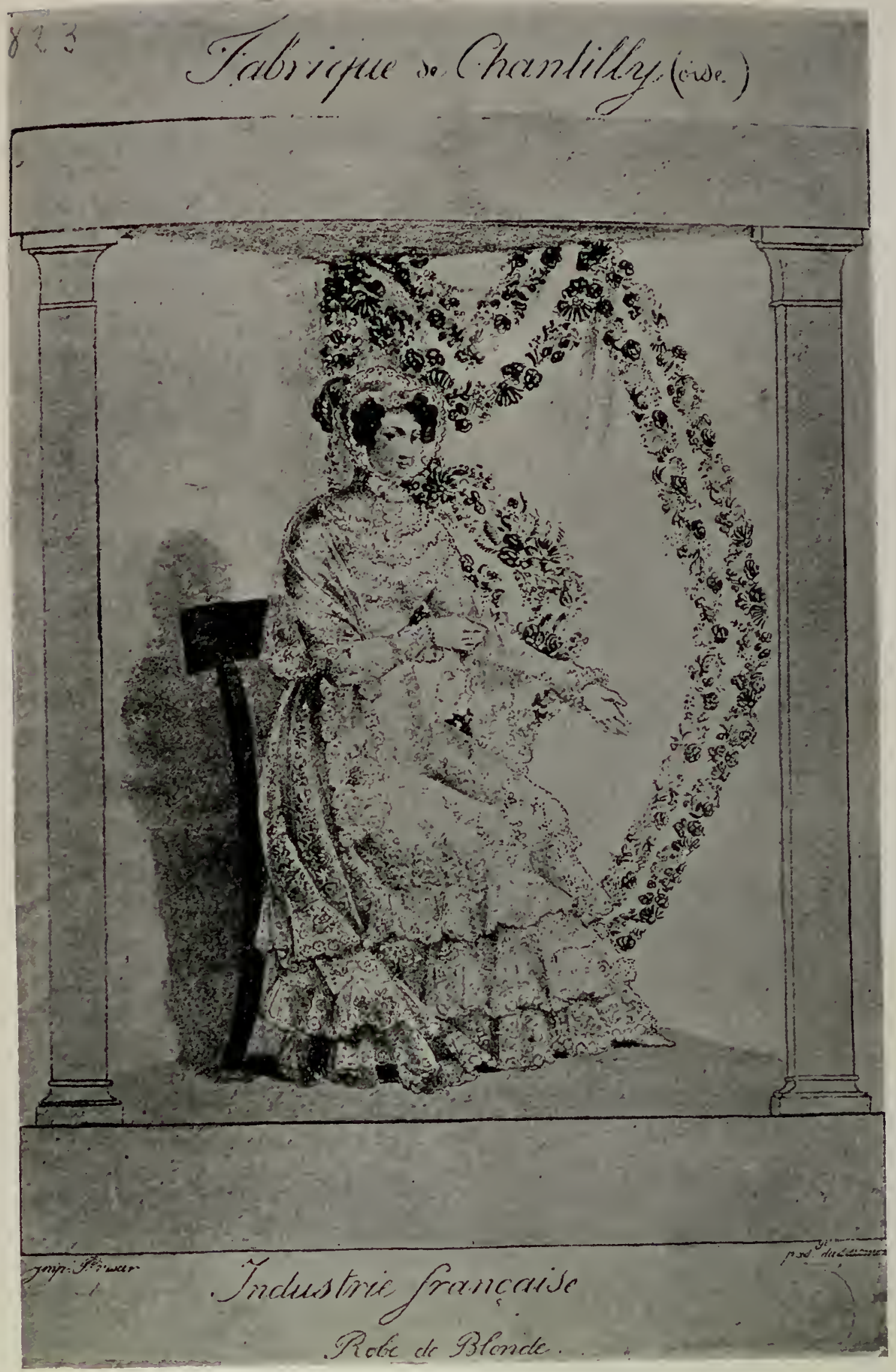

XXV. FROM AN ENGRAVING IN THE MUSÉE CARNAVALET 


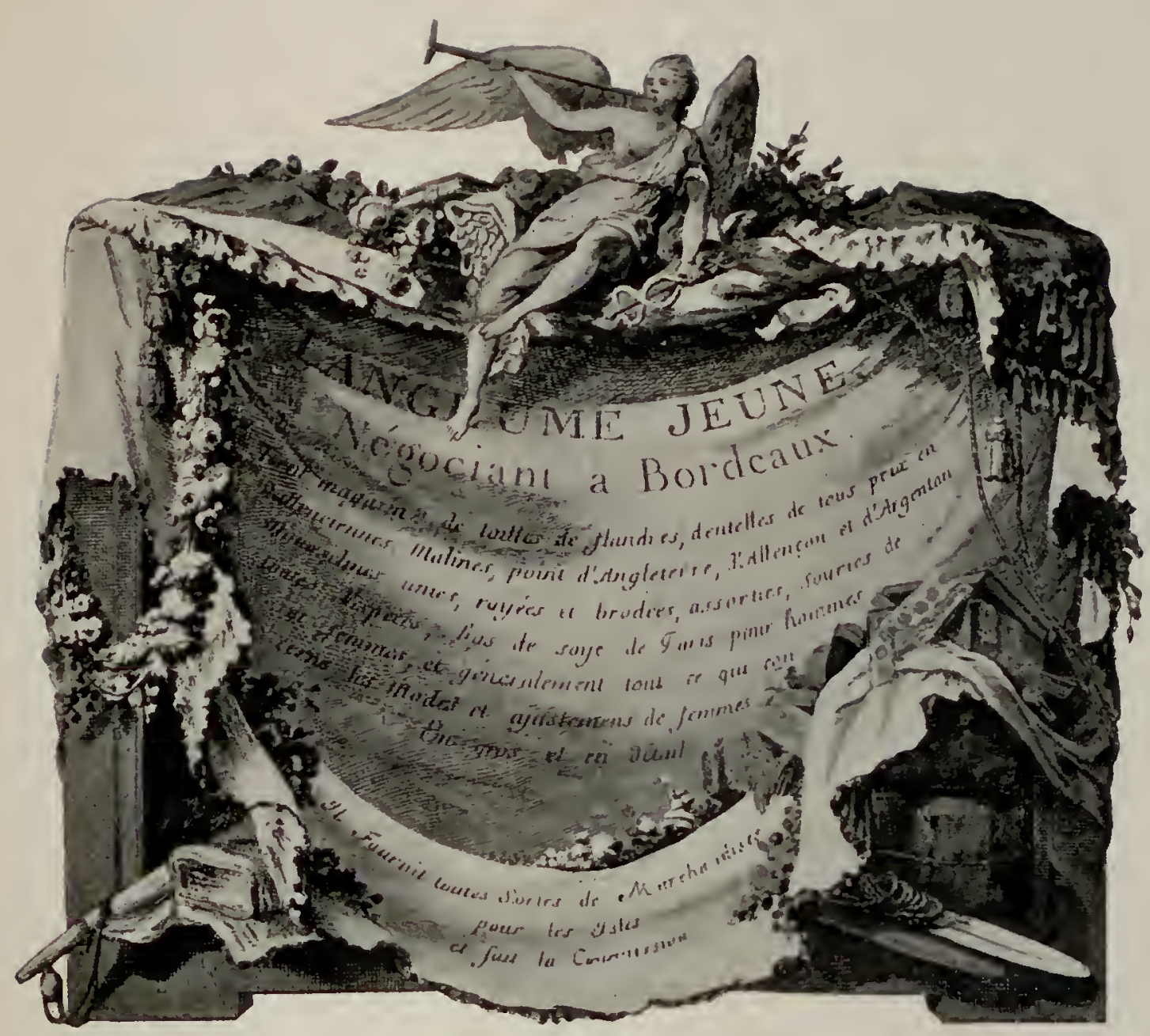

XXVI. ADDRESS OF A LACE-MERCHANT

PERIOD OF LOUIS XYI 



\section{$\left[9^{3}\right]$}

very marked when we compare the prospectus just described with that of Langlumé Jeune, dealer in laces at Bordeaux, framed with a charming design of the period of Louis XVI.

Under Louis-Philippe laces were much in vogue, but the designs of this period can hardly be cited as models of style. India shawls also were in high esteem, and a bride would have thought herself neglected, were not two or three in her marriage chest. The scarfs and rows of flounces then in fashion, can be seen in the picture of Queen Marie Amélie in the Musée de Versailles, but they lack character, and the bunches of flowers in the design, badly arranged and very conventional, often resemble the palms of the cashmere shawls.

Under the Second Empire, there was a large consumption of lace. It was the time when, according to Félix Aubry (Report on the International Exhibition in London, I85 I), hand-made lace in France gave work to 240,000 women.

Very beautiful were the wedding dresses of the Empress Eugénie, trimmed with deep flounces of Point d'Alençon. The city of Paris offered a cradle for the baptism of the Prince Imperial, the rich trimmings and curtains of which were of lace worked with a semé of bees, the Imperial crown filling each corner.

The International Exhibitions of 1855 and 1867 in Paris were eras of great prosperity for hand-made lace. 


\section{[94]}

France exporled to all countries, supplying Havana and the whole of Spanish America with mantillas of the blonde of Caen, and of Bayeux. Large picces of lace were then made - court trains, skirts, and shawls in deep points. One of the latter, made of black lace, was shown at the Retrospective Exhibition, after receiving a medal at the Exhibition of $186_{7}$. The design has bunches of roses, the leaves being shaded in working by the diflerent thickness of the threads employed - a novelty at that time, but one which has since been used for all kinds of lace.

But these commercial successes of hand-made lace were followed by a crisis which can be attributed to many causes: the war of 1870 , the lessening of $\mathrm{cx}$ portations, the increase of tailor-made costumes and sporting attire in the gay world - all of which impediments have much lessened the consumption of lace. A large number of lace-workers were obliged to leave a trade which no longer assured them a certain means of earning their daily bread.

These troublous times, far from diminishing the artistic value of hand-made lace, conduced to more energetic efforts on the part of manufacturers to retain for their industry an acknowledged pre-eminence. Never before has so much effort been made to discover the construction of ancient stitches, the tradition of which was lost. In France, Belgium, and Austria, much effort has been devoted to renewing the 


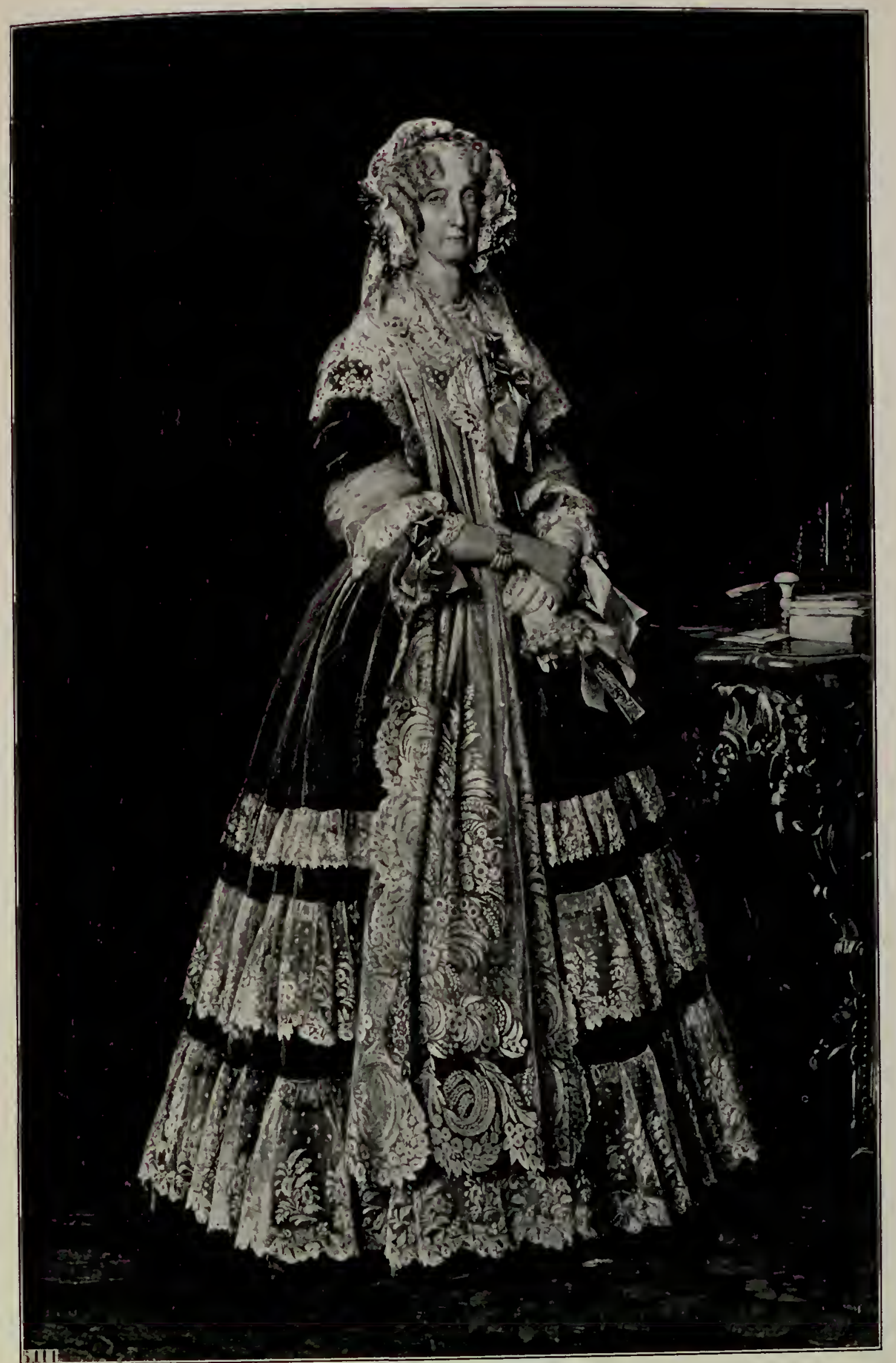

XXVII. QUEEN MARIE-AMÉLIE

PAINTING BY WINTERHALTER

MUSÉE DE VERBAILLES 



\section{$[97]$}

designs, and finding fresh decorative effects, in which the utmost advantage could be taken of the technical resources, thus establishing the making of hand-made lace as an arl-industry, worthy of appearing in Museums, and in the Annual Exhibitions. ${ }^{1}$ In this respect, considerable progress has been made in the whole production of lace, since the beginning of the nineteenth century, a progress which foreshadows a further renaissance of this beautiful industry.

A curious instance of these tentative efforts is the book-cover for the lext, in Norman dialect, of the Bull of the Immaculate Conception, in the Library of the Vatican. It is ornamented with the escutcheons of the Archbishop of Rouen, and of his suffragans, the Bishops of Bayeux, Évreux, Séez, and Coutances, who had it executed at Bayeux. The arms of the city of Rouen are worked in relief in the center, on a grounding of Point d'Argentan, while the other four in the angles of the frame are of Point de Colbert.

To recapitulate - however incomplete this part of the Retrospective Exhibition, it nevertheless showed an ensemble of sufficient importance to reaffirm the high position occupied by the laces of France. It was important to show how, through its artistic traditions, and the delicacy and perfection of the work, lace can aspire to a high place in those Courts of Art and In-

\footnotetext{
1 The remarkable revival of embroidery and lace in Italy coincides with that of the northern countries. Note by the Translator.
} 


$$
\left[9^{8}\right]
$$

dustry where, by order of merit, are classed all the products of human activity.

We cannot leave this subject without expressing our thanks to the collectors who have allowed us to reproduce the specimens which they lent to the Exhibition; without these illustrations, our text would lose its chief interest. 


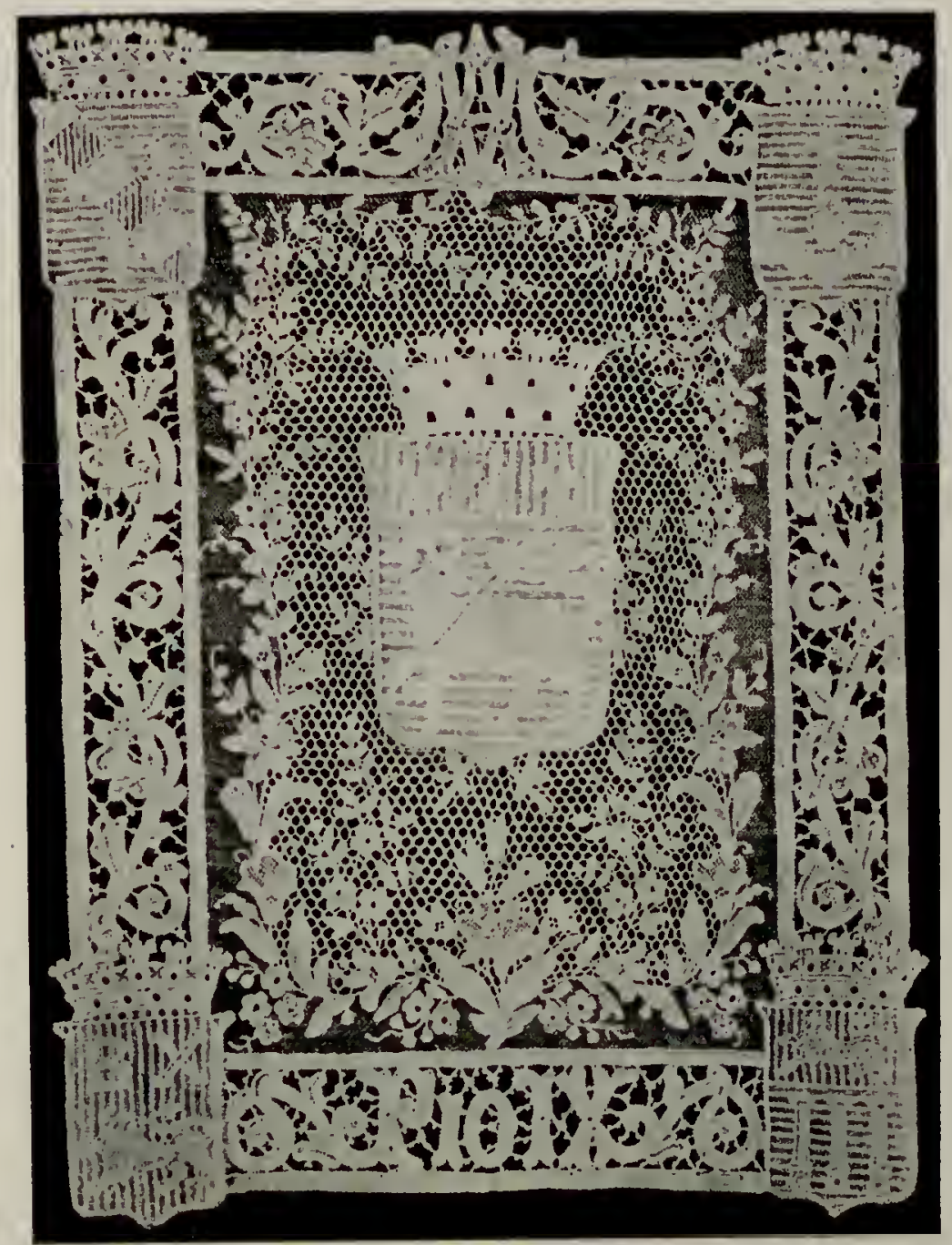

XXVIII. BOOK-COVER IN POINT COLBERT

AND POINT D'ARGENTAN. NINETEENTH CENTURY LIBRARY OF THE VATICAN 


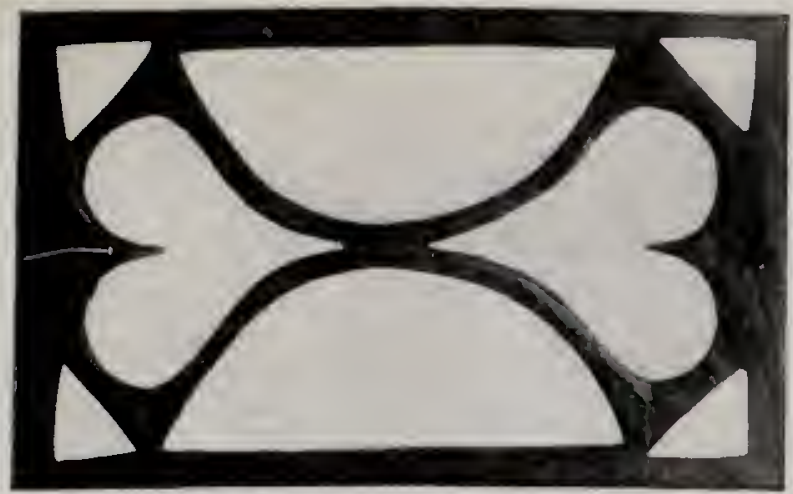

EIGHTEENTH CENTURY, AUVERGNE

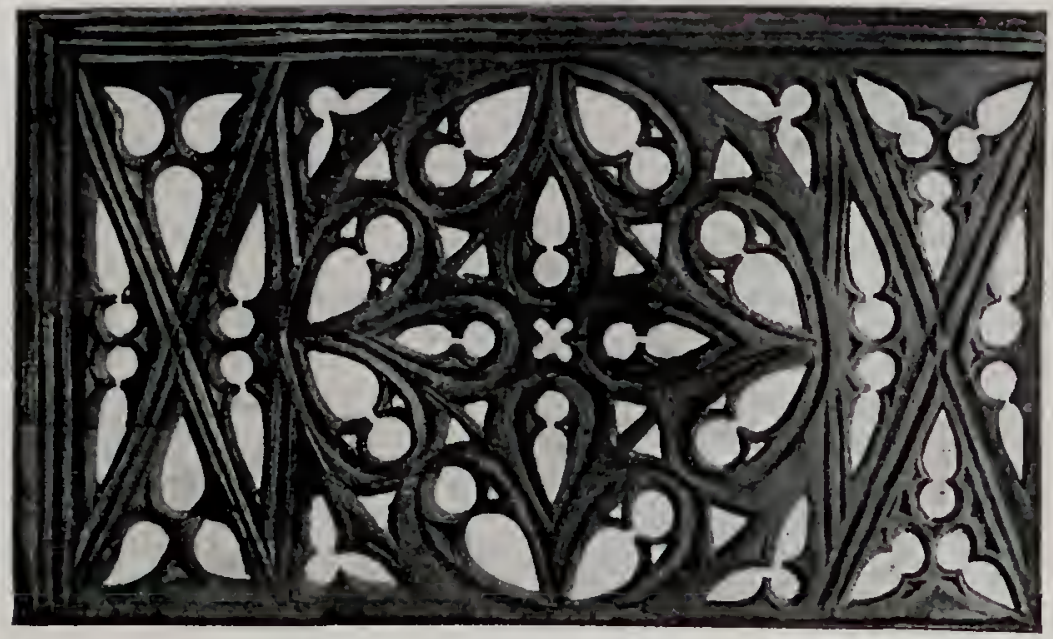

SEVENTEENTI CENTURY, AUVERGNE

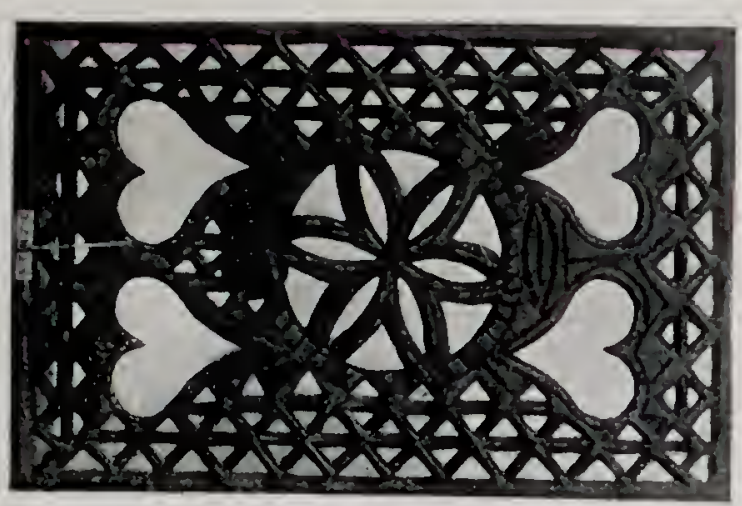

XXIX. WINDERS FOR LACE. MUSEE DU TROCADÉRO 


\section{INTERNATIONAL EXHIBITION \\ OF I 900}

\section{French Section}

General Commissioner of the Exhibilion

M. ALFRED PIGARD

Assislant Director-General of the Exhibition in charge of the French Section

M. STÉPHANE DERVILLÉ

Depuly in charge of the French Section M. ALBERT BLONDEL

Depuly in special charge of the Cenlennial Collections M. FRANC̣OIS CARNOT

Archilect of the Centennial Collections

M. JAGQUES HERMANT 


\section{COMMITTEE OF ARRANGEMENT FOR THE CLASS 84}

\section{OFFICERS}

President: M. Ancelot (Alfred) O. $\frac{x}{x}$, Former President of the General Association of the Commerce and Industry of Weaving, and of Textile Fabrics. Member of the Chamber of Commerce of Paris, and of the Permanent Commission of Custom Valuations.

Vice-President: M. Hénon (Henri) President of the Syndical Chamber of the Manufacturers of Tulles and Laces. Treasurer of the Chamber of Commerce of Calais. Member of the Permanent Commission of Custom Valuations.

Recorder: M. MARTin (Georges) President of the Chamber of Laces and Embroideries.

Secretary: M. Goulette (Eugène) President of the Syndical Chamber of Passementerie, Mercery, Buttons, and Ribbons of Paris.

Treasurer: M. Noirot-Biais (Henri).

\section{MEMBERS}

MM. Baboin (Emile).

Bellan (Léopold) Paris.

Crouvezier (Charles).

Darquer (Adolphe) President of the Chamber of Commerce of Calais.

GuYe (Henri) Judge of the Tribunal of the Commerce of the Seine.

Hetzey (Georges). 
MM. Isa Ac (Auguste) President of the Chamber of Commerce of Lyons.

LEFÉBURE (Ernest) O. 叔.

Loreau (Alfred) $\frac{x}{x}$, Engineer of Arts and Manufactures. Former Deputy General Councillor of the Loiret. Regent of the Bank of France.

Neveu (Etienne) 侪.

Rousse L (Alcide) Designer.

Sébastien (Gustave) Member of the Tribunal of the Chamber of Commerce of Saint-Quentin (Aisne).

VAChon (Marius) Advertising Agent.

\section{ARCHITECT}

M. De Montarnal (Joseph de Guirard) Architect for the Government (Diplômé).

COMMISSION OF THE RETROSPECTIVE COLLECTIONS

MM. LoREAU (Alfred).

Martin (Georges).

Noiret-Biais (Henri).

Recorder for the Retrospective Collection

(Section of Laces)

M. LEFÉbuRE (Ernest). 
(c) be litheraida pregs

CAMBRIDGE . MASSACIUSETTS

U . S . A 



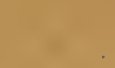

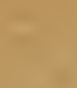

$\sqrt{2}$

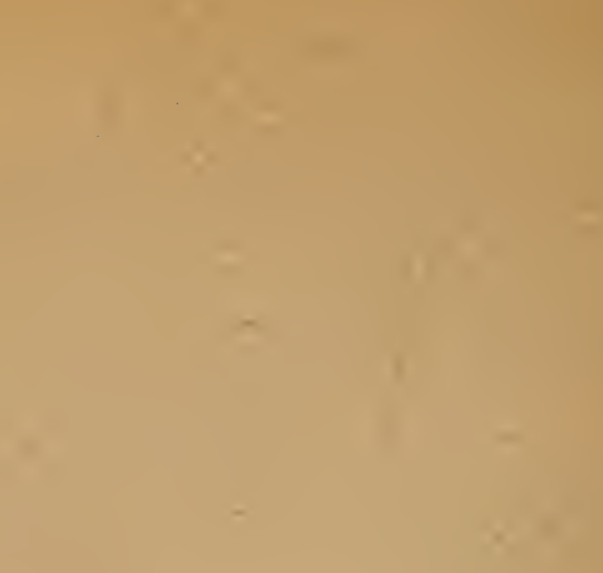

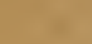

1

$7+\frac{1}{4}$

$\sqrt{10}$

列

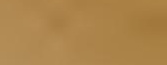

4

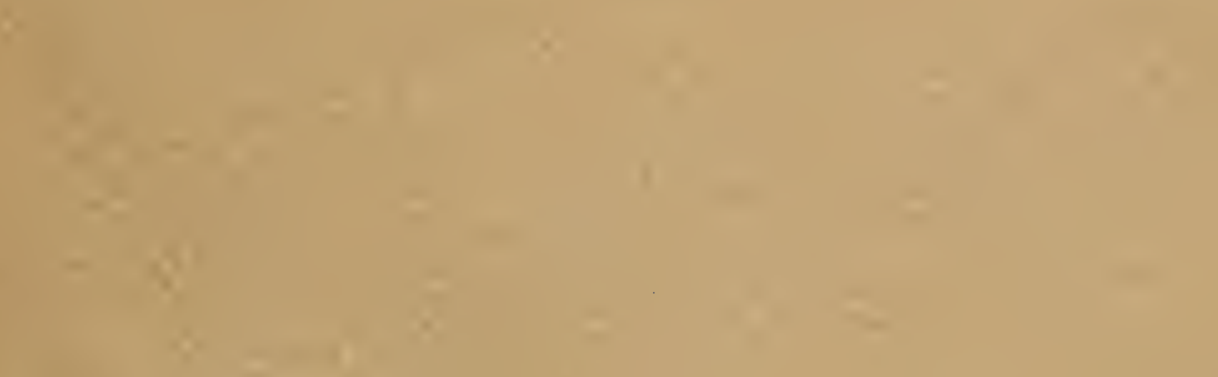

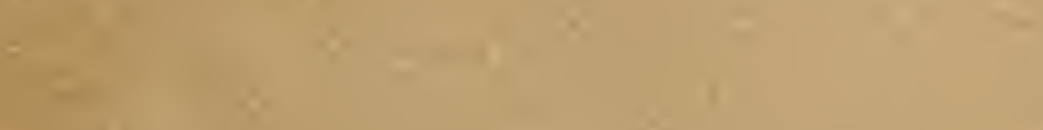

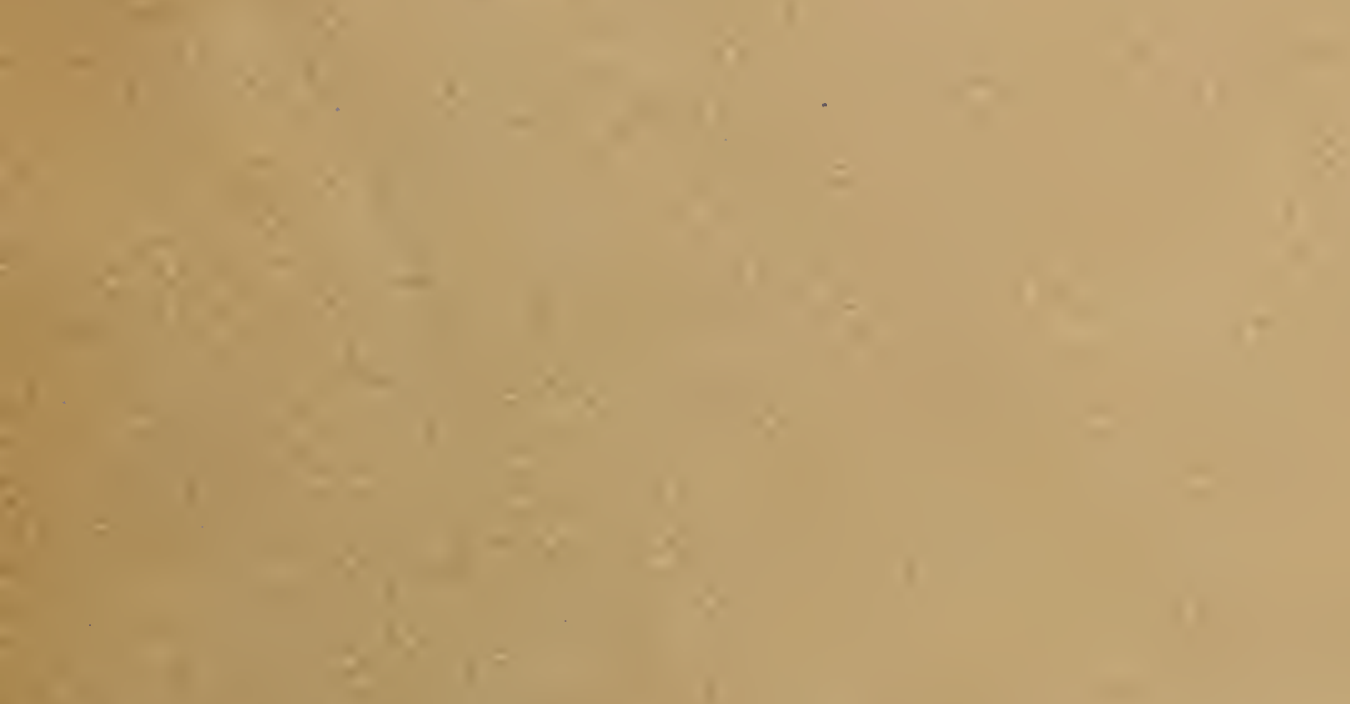

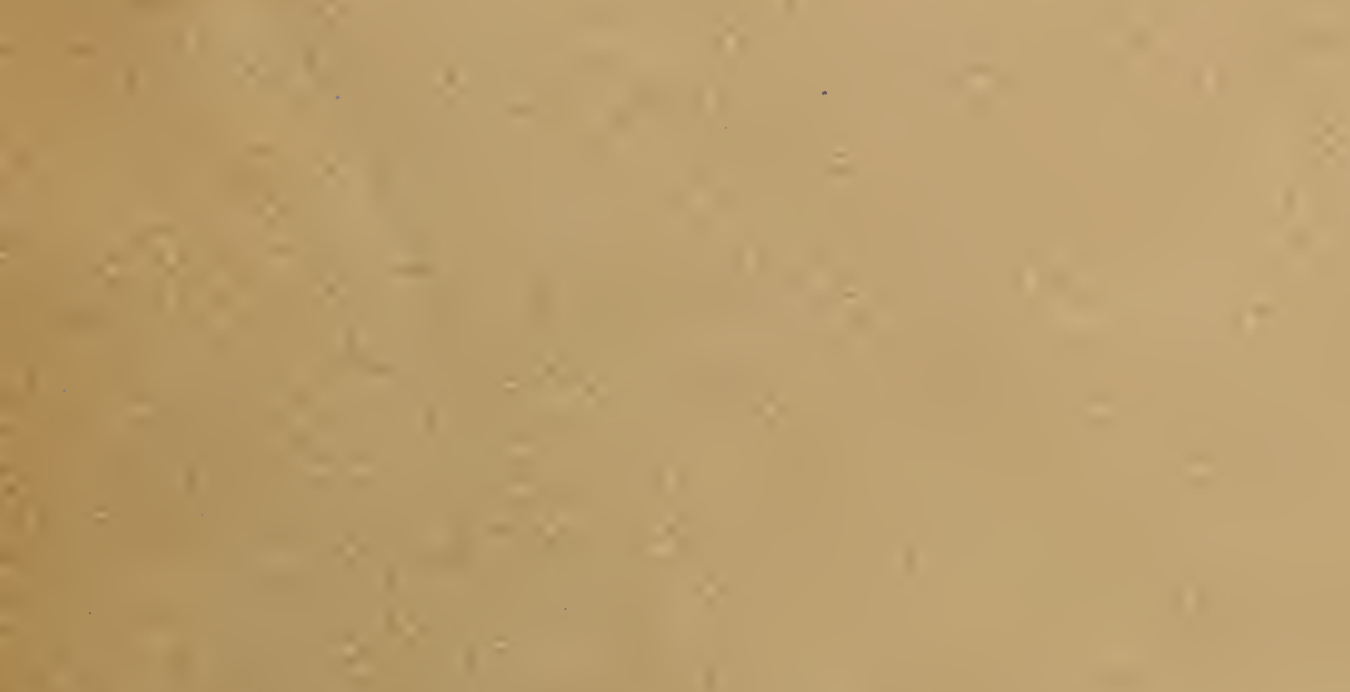

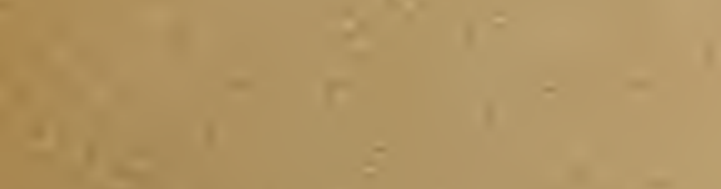

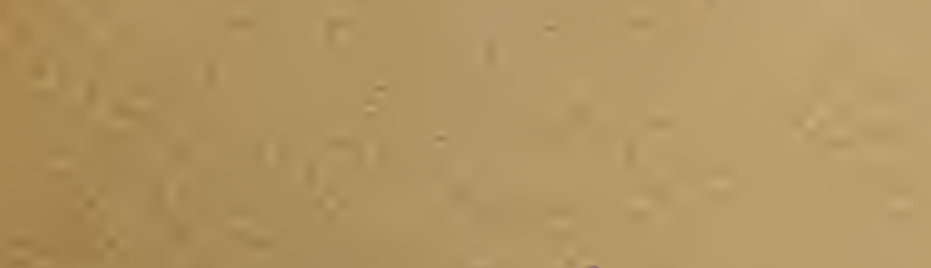

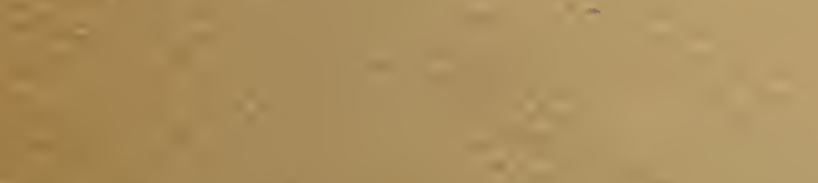

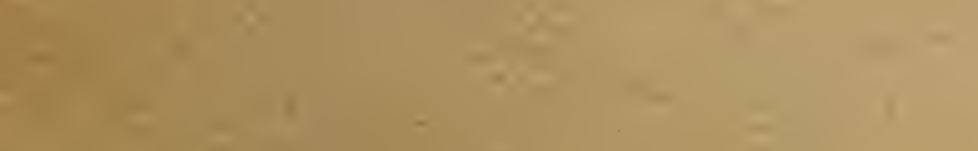

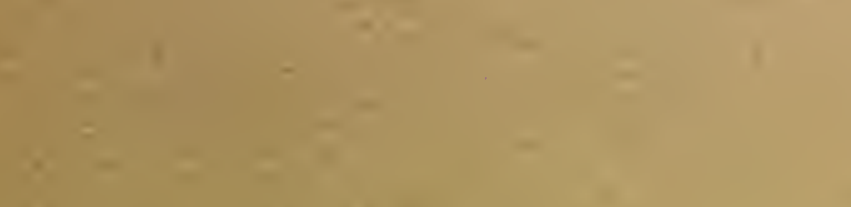

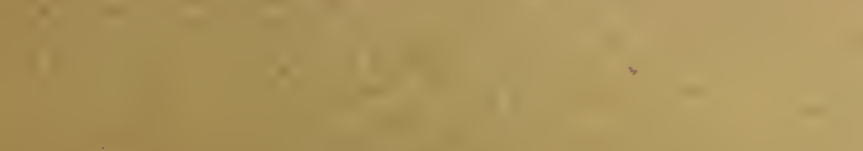

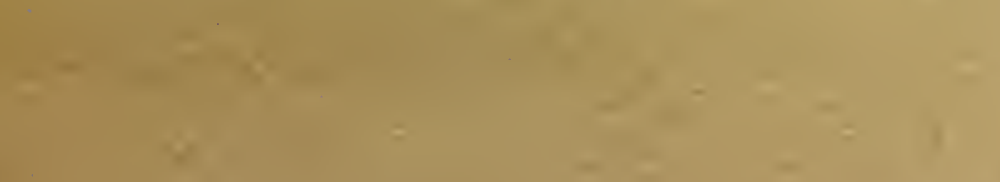

Y

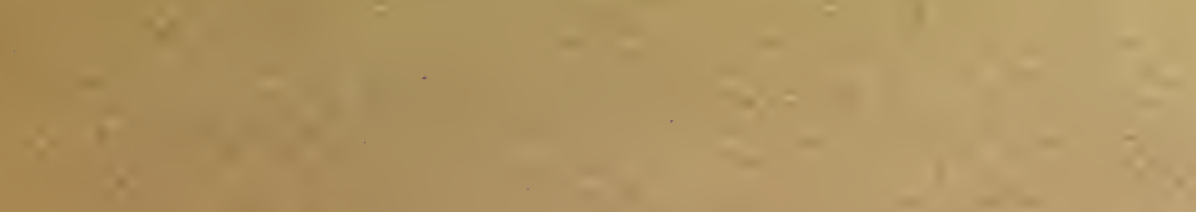

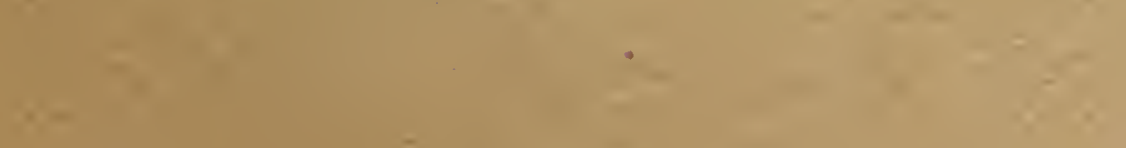

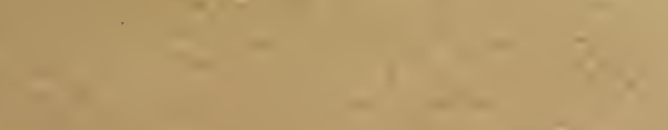

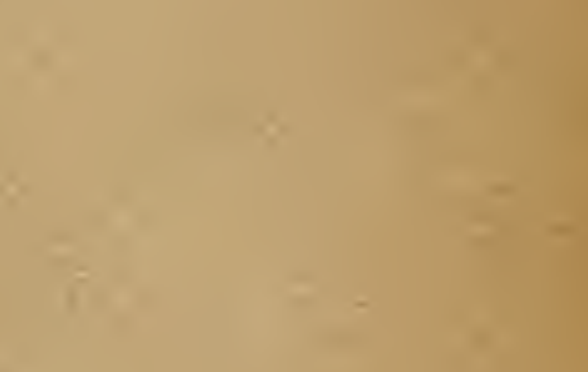

$x$

*

a

10

$-$

$-1-$

$x+2$

$x^{2}+-$ 



39088015478803 